\title{
Efficient Chemoenzymatic Synthesis, Cytotoxic Evaluation, and SAR of Epoxysterols
}

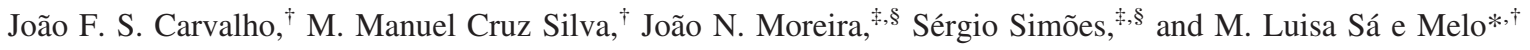 \\ Centro de Estudos Farmacêuticos, Laboratório Química Farmacêutica, Faculdade de Farmácia, Universidade de Coimbra, \\ 3000-548 Coimbra, Portugal, Laboratório de Tecnologia Farmacêutica, Faculdade de Farmácia, Universidade de Coimbra, \\ 3000-548 Coimbra, Portugal, Center for Neurosciense and Cell Biology, University of Coimbra, Portugal
}

Received March 27, 2009

\begin{abstract}
A library of diastereomerically pure epoxysterols, prepared by combining chemical and enzymatic methodologies, was evaluated for cytotoxicity toward human cancer and noncancer cell lines. Unsaturated steroids were oxidized by magnesium bis(monoperoxyphthalate) hexahydrate in acetonitrile, and the resulting epimeric epoxides were enzymatically separated using Novozym 435 or lipase AY. Some of the synthesized epoxysterols have potent cytotoxicity and higher activity on cancer cell lines HT29 and LAMA-84.
\end{abstract}

\section{Introduction}

Oxygenated derivatives of cholesterol, known as oxysterols, represent a group of biomolecules gaining much attention in recent years due to their relevant bioactivities. ${ }^{1-4}$ Oxysterols have been detected in appreciable quantities in human tissues and fluids ${ }^{5}$ and have been implicated in a number of important biological processes such as regulation of cholesterol homeostasis, atherosclerosis, and cytotoxicity. ${ }^{5-8}$

Naturally occurring $5 \alpha, 6 \alpha_{-}^{-9-11}$ and $5 \beta, 6 \beta$-epoxysteroids ${ }^{12,13}$ have shown relevant cytotoxic effects in tumor cells. For instance, the $3 \beta$-hydroxy- $5 \beta, 6 \beta$-epoxy moiety is present in natural withanolides like tubocapsenolide $\mathrm{A}$, recently identified as a potent inhibitor of MDA-MB-231 cell proliferation. ${ }^{13}$

Epoxides are three-membered cyclic ethers that have specific reactivity patterns owing to the highly polarized oxygen-carbon bonds in addition to a highly strained ring. ${ }^{14}$ Some epoxides are responsible for electrophilic reactions with critical biological targets such as DNA and proteins, leading to mutagenic, toxic, and carcinogenic effects. ${ }^{15-17}$

Although there are many applications for racemic epoxides, the demand of enantiomerically pure epoxides has increased in the recent years. Enantiopure epoxides are useful synthetic intermediates for the chemical and pharmaceutical industries because their synthetic versatility renders them valuable intermediates for further enantiocontrolled transformations. They are essential in the synthesis of important drugs such as (S)-timolol, a $\beta$-adrenergic blocking agent, indinavir, a HIV protease inhibitor, and diltiazem, a calcium channel blocker. In the steroid field, several 4,5-epoxysteroids are intermediates in the synthesis of biologically active compounds like aromatase inhibitors ${ }^{18,19}$ and anti-HIV agents ${ }^{20,21}$ among others. ${ }^{22}$ Furthermore, ringopening of $5 \alpha, 6 \alpha$-epoxysteroids gives access to contraceptives, anti-inflammatory agents, and enzymatic inhibitors. ${ }^{23-25}$

The stereoselectivity of most steroid epoxidation methods is dictated by the higher hindrance of the $\beta$-face on the steroid scaffold. Peroxyacids afford predominantly $5 \alpha, 6 \alpha$-epoxides, while potassium permanganate/inorganic salts, chiral ketones/ oxone, and transition metal complexes in the presence of air or

* To whom correspondence should be addressed. Phone: +351239 859990. Fax: +351239827030. E-mail: samelo@ci.uc.pt.

${ }^{\dagger}$ Centro de Estudos Farmacêuticos, Laboratório Quírmica Farmacêutica, Faculdade de Farmácia, Universidade de Coimbra.

* Laboratório de Tecnologia Farmacêutica, Faculdade de Farmácia, Universidade de Coimbra.

${ }^{\S}$ Center for Neurosciense and Cell Biology, University of Coimbra. molecular oxygen as oxidant, among other methods, give access to $\beta$-epoxides. Steroid epoxidation methods were recently reviewed by Salvador et al. ${ }^{26}$ However, the majority of these methods fail to give diastereomerically pure $\alpha$ - and $\beta$-epoxysterols.

Biocatalysis has emerged as a valuable strategy to access epimerically pure compounds by taking advantage of the stereoselective properties of enzymes. ${ }^{27,28}$

Biocatalytic epoxidation can be achieved through oxidizing enzymes such as monooxygenases (e.g., cytochromes P450s or nonheme monooxigenases) or haloperoxidases (e.g., chloroperoxidases). ${ }^{29,30} \mathrm{P} 450 \mathrm{~s}$ are direct asymmetric epoxidation catalysts, whereas haloperoxidases produce epoxides indirectly from alkenes by initial halohydrin formation and subsequent ring closure by halohydrin epoxidase. Several limitations have hampered their synthetic application, however, a considerable effort in protein engineering has been done, and enzyme direct evolution can be in the future the solution to overcome such limitations. ${ }^{31,32}$

Other methodologies for the synthesis of epimerically pure products can be performed by the conjugation of chemical and enzymatic approaches. In this way, the use of hydrolytic enzymes can be a useful tool to separate epimeric mixtures of epoxides.

Specifically, epoxide hydrolases can be effectively used for hydrolytic kinetic resolution. ${ }^{33}$ They seem to be a promising tool for the discrimination of epoxide mixtures because they act directly on the epoxide ring, being independent of any other functionality. Furthermore, epoxide hydrolases are cofactor independent, present good stability, and can be used in the presence of organic solvents. However its application has been limited due to the small number of enzymes available, limited substrate acceptance, and low catalytic efficiency.

On the other hand, lipases are among the most frequently used enzymes, because they are ease to handle, commercially available, stable, even in organic solvents, and are cofactorindependent. Lipases are able to perform enantioselective hydrolytic reactions and catalyze the formation of a wide range of ester and amide bonds. Moreover, these enzymes can be used for the diastereomeric resolution of epoxide mixtures by acylation/deacylation of a hydroxyl group closely located to the stereocenter.

Our group has studied the ability of lipases to separate mixtures of 5,6-epoxysteroids through selective acylation of the $3 \beta$-hydroxyl group or deacylation of the acetoxy counterpart. ${ }^{34}$ 
Scheme 1. MMPP Epoxidation of Cholest-5-enes

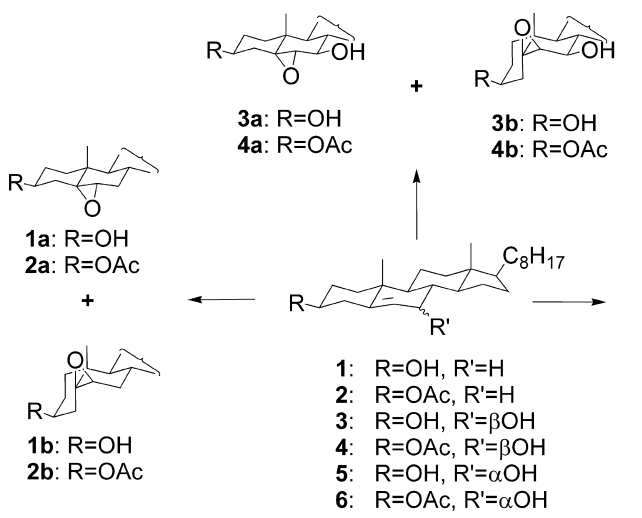

Scheme 2. MMPP Epoxidation of Cholest-4-enes and Cholest-5-enes
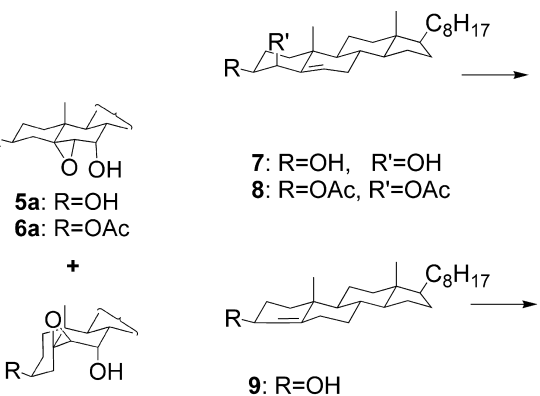

5b: $\mathrm{R}=\mathrm{OH}$ 6b: $R=O A c$

In this study, the stereoselectivity of lipases toward epoxysterols was further explored in order to obtain pure epoxides from the diastereomeric mixture obtained by chemical oxidation. Compounds with extra hydroxyl groups in the steroid nucleus were studied under the same discriminative conditions. Furthermore, the hydrolysis of $3 \beta$-acetoxy esters in the presence of the sensitive oxirane functionality was explored.

Specifically, we report the synthesis of a series of cholestan4,5- and -5,6-epoxide mixtures by a fast and high-yielding magnesium bis(monoperoxyphthalate) hexahydrate (MMPP) oxidative protocol ${ }^{35}$ and the enzymatic discrimination of the diastereomerically pure $\alpha$ - and $\beta$ - epoxides using lipases AY (from Candida cylindracea) and Novozym 435 (from Candida antarctica) as complementary stereoselective catalysts for the acylation/deacylation of the epoxysterols. Diastereomerically pure epoxides were tested for cytotoxicity in two cancer cell lines (HT29 and LAMA-84) and in a normal fibroblast cell line (BJ). Some of the epoxides prepared showed high cellular toxicity, and structure-activity correlations were drawn.

\section{Results and Discussion}

The known bioactivity of natural and synthetic epoxysterols prompted us to prepare a library of such cholestane derivatives by combining chemical and enzymatic procedures to further correlate their structure with cytotoxicity.

Some of the epoxides chemoenzymatically synthesized herein are oxidative analogues of sterol compounds produced in vivo, such as $4 \beta$-hydroxycholesterol, a quantitatively important oxysterol in circulation, ${ }^{36,37}$ and $7 \alpha$-hydroxycholesterol, which is the first step product in the most important pathway for bile acid biosynthesis. ${ }^{38} 7 \beta$-Hydroxycholesterol, present in minor levels in plasma, is related to the presence of oxidatively modified LDL and oxidative stress. ${ }^{5,39}$ Moreover, $7 \beta$-hydroxycholesterol and $5 \beta, 6 \beta$-epoxycholesterol derivatives are known to exert cell death by apoptotic processes in a human monocytic U937 cell line. ${ }^{40}$ Therefore, oxysterol epoxides, being direct oxidative intermediates of endogenously oxysterols, can possibly have interesting biological roles in vivo.

Chemical Synthesis of Epoxides. A protocol for $\mathrm{MMPP}^{a}$. mediated epoxidation in acetonitrile under reflux, recently developed by our group, ${ }^{35}$ was applied to access the epoxysterols shown in Schemes 1 and 2.

${ }^{a}$ Abbreviations: MMPP, magnesium bis(monoperoxyphthalate) hexahydrate; LDL, low density lipoprotein; $t \mathrm{BHP}$, tert-butyl-hydroperoxide; MDR, multidrug resistance; N435, Novozym 435; LAY, lipase AY; VAC, vinyl acetate; OCT, $n$-octanol; ATCC, American Type Culture Collection; DSMZ, Deutsche Sammlung von Mikroorganismen and Zellkulturen GmbH; PS, penicillin and streptomycin; CM, culture medium; iFBS, inactivated fetal bovine serum.

$$
\begin{aligned}
& \text { 7: } R=O H, \quad R^{\prime}=O H \\
& \text { 8: } R=O A c, R^{\prime}=O A C
\end{aligned}
$$
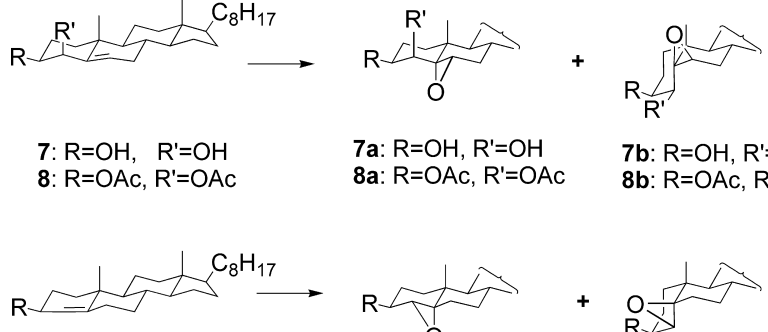

7a: $\mathrm{R}=\mathrm{OH}, \mathrm{R}^{\prime}=\mathrm{OH}$

8a: $R=O A c, R^{\prime}=O A c$

7b: $\mathrm{R}=\mathrm{OH}, \mathrm{R}^{\prime}=\mathrm{OH}$ 8b: $R=O A c, R^{\prime}=O A c$
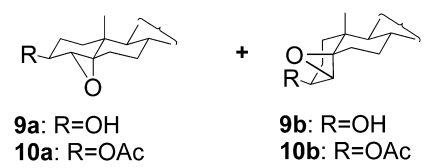

9: $\mathrm{R}=\mathrm{OH}$

10: $R=O A C$

10a: $R=O A c$

10b: $R=O A c$
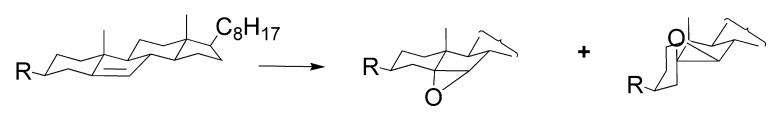

11: $\mathrm{R}=\mathrm{OH}$

12: $\mathrm{R}=\mathrm{OAC}$

11a: $\mathrm{R}=\mathrm{OH}$

12a: $R=O A c$

11b: $\mathrm{R}=\mathrm{OH}$

12b: $R=O A c$

The use of an equimolar amount of MMPP under reflux in acetonitrile revealed to be a very fast and efficient method to obtain epoxysterols, as summarized in Table 1. Epoxidation of compounds $\mathbf{1}, \mathbf{7}, \mathbf{8}, \mathbf{9}$, and 11 was already explored by our group using the above-mentioned oxidative procedure. Herein we move our attention to the synthesis of epoxysterols bearing an allylic 7-hydroxyl group. 7-Oxygenated steroids are widespread in mammals, birds, fish, and plants, and there is evidence about the importance of the 7-hydroxylation pattern for biological function. $^{41}$

The preparation of $\Delta^{5}$-7-oxygenated cholesteryl derivatives started with the allylic oxidation of cholesteryl acetate using $t$-butyl-hydroperoxide ( $t \mathrm{BHP})$ and copper iodide. ${ }^{42}$ The described procedure was modified by adding $t \mathrm{BHP}$ portionwise ( 5 portions each, $45 \mathrm{~min}$, during $3 \mathrm{~h}$ ) to the reaction mixture. 7-oxo-Cholest-5-en-3 $\beta$-yl-acetate was isolated by flash chromatography in $50 \%$ yield. The addition of $t$ BHP portionwised resulted in higher product yields, probably due to the avoidance of the free-radical chain decomposition of $t \mathrm{BHP} .{ }^{43}$

The $7 \alpha$-hydroxy derivatives were obtained by reduction of the corresponding 7-oxo-derivatives with L-Selectride. ${ }^{44}$ In our procedure, the reduction of 7-oxo-cholest-5-en-3 $\beta$-yl acetate with this reagent and additional stirring (35 min.) with aqueous solutions of $\mathrm{NaOH}$ and $\mathrm{H}_{2} \mathrm{O}_{2}$ afforded, after flash chromatography, the pure $7 \alpha$-hydroxy-choleste-5-en- $3 \beta$-yl acetate (6) and cholest-5-ene-3 $\beta, 7 \alpha$-diol (5) in $45 \%$ and $46 \%$ yield, respectively.

$7 \beta$-Hydroxy derivatives were easily prepared in a fast and highly stereoselective manner from 7-ketocholesteryl acetate using sodium borohydride in the presence of cerium trichloride. ${ }^{44}$ The pure $7 \beta$-hydroxy-cholest-5-en- $3 \beta$-yl acetate (4) was obtained in $95 \%$ yield. Cholest-5-ene-3 $\beta, 7 \beta$-diol (3) was isolated after alkaline hydrolysis in $90 \%$ yield. The same reduction protocol was used to convert cholestenone into cholest-4-en$3 \beta$-ol (9), although being less selective.

The whole 7-hydroxy-cholest-5-ene derivatives $(\mathbf{3}, \mathbf{4}, \mathbf{5}$, and 6) prepared were then oxidized using MMPP in acetonitrile under reflux. It is well recognized the syn-directing effect of allylic hydroxyls, both in acyclic ${ }^{45}$ and cyclic compounds as steroids, ${ }^{46}$ in the outcome of epoxidation stereoselectivity. Herein, we have observed the same effect, specifically in the epoxidation of cholest-5-ene-3 $\beta, 4 \beta$-diol (7), where the introduction of an allylic $\beta$-hydroxy group in ring $\mathrm{A}$, in comparison to cholesterol, results in the higher formation of the $\beta$-epoxide (entries 1 and 8 , Table 1). Thus it is expected that an allylic 
Table 1. MMPP Epoxidation of $\Delta^{4}$ - and $\Delta^{5}$-Cholestenes

\begin{tabular}{|c|c|c|c|c|c|c|c|c|}
\hline entry & substrate $(\mathrm{mmol})$ & $\operatorname{MMPP}(\mathrm{mmol} / \mathrm{mmol})^{a}$ & solvent $(\mathrm{mL} / \mathrm{mmol})$ & temp & time & product & yield $(\%)^{b}$ & epoxide ratio $\alpha: \beta(\%)^{c}$ \\
\hline 1 & $1 / 1.200$ & 1.1 & $15 / \mathrm{CH}_{3} \mathrm{CN}$ & reflux & $10 \mathrm{~min}$ & $\mathbf{1 a}, 1 \mathbf{b}$ & 83 & $78: 22$ \\
\hline 2 & $3 / 0.248$ & 2.5 & $15 / \mathrm{CH}_{2} \mathrm{Cl}_{2} / \mathrm{H}_{2} \mathrm{O}^{f}$ & $\mathrm{rt}$ & $53 \mathrm{~h}$ & $\mathbf{3 a}, \mathbf{3 b}$ & 92 & $52: 48$ \\
\hline 3 & $3 / 0.507$ & 1.1 & $30 / \mathrm{CH}_{3} \mathrm{CN}$ & reflux & $15 \min$ & $\mathbf{3 a}, \mathbf{3 b}$ & 89 & $44: 56$ \\
\hline 5 & $4 / 0.235$ & 1.1 & $30 / \mathrm{CH}_{3} \mathrm{CN}$ & reflux & $25 \mathrm{~min}$ & $4 a, 4 b$ & 86 & $50: 50$ \\
\hline 6 & $5 / 0.175$ & 1.1 & $30 / \mathrm{CH}_{3} \mathrm{CN}$ & reflux & $25 \mathrm{~min}$ & $5 \mathbf{a}, \mathbf{5 b}$ & 78 & $89: 11$ \\
\hline 7 & $6 / 0.180$ & 1.1 & $30 / \mathrm{CH}_{3} \mathrm{CN}$ & reflux & $40 \mathrm{~min}$ & $6 \mathbf{a}, 6 \mathbf{b}$ & 82 & $86: 14$ \\
\hline 8 & $7 / 0.550$ & 1.1 & $15 / \mathrm{CH}_{3} \mathrm{CN}$ & reflux & $25 \mathrm{~min}$ & $7 \mathbf{a}, 7 \mathbf{b}$ & 82 & $43: 57$ \\
\hline 11 & $11 / 0.268$ & 1.1 & $15 / \mathrm{CH}_{3} \mathrm{CN}$ & reflux & $2 \min$ & 11a,11b & 80 & $99: 1$ \\
\hline
\end{tabular}

${ }^{a}$ mmol of MMPP per mmol of substrate. ${ }^{b}$ Isolated yield by flash chromatography. ${ }^{c}$ Calculated by ${ }^{1} \mathrm{H}$ NMR integration in the crude product. ${ }^{d}$ Addition of MMPP portionwised until complete substrate consumption: initial addition of $1.1 \mathrm{mmol}$ of MMPP, with subsequent additions of $0.5 \mathrm{mmol}$ each 3 days. ${ }^{e}$ Addition of MMPP portionwised (1.017 mmol per h) until complete substrate consumption. ${ }^{f}$ Addition of $100 \mu \mathrm{L}$ of $\mathrm{H}_{2} \mathrm{O}$ per mmol of MMPP.

Table 2. Enzymatic Discrimination of Epoxycholestanes ${ }^{a}$

\begin{tabular}{|c|c|c|c|c|c|c|}
\hline entry & substrate $(\mathrm{mg})$ & epoxide ratio $\alpha: \beta(\%)^{b}$ & enzyme $^{c}(\mathrm{mg})$ & reagent $^{d}(\mathrm{~mL})$ & time (days) & product $^{e}$ \\
\hline 1 & $1 \mathbf{a}, 1 \mathbf{1 b} / 75$ & $78: 22$ & N435/42 & VAC/0.5 & 1 & $\mathbf{1 a}(77 \%)+\mathbf{2 b}(20 \%)$ \\
\hline 2 & $\mathbf{1 a}, \mathbf{1 b} / 140$ & $78: 22$ & $\mathrm{LAY} / 218$ & $\mathrm{VAC} / 1$ & 1 & $\mathbf{1 a}, \mathbf{1 b}(18 \%, 13: 87)+\mathbf{2 a}, \mathbf{2 b}(80 \%, 94: 06)$ \\
\hline 3 & $\mathbf{1 a}, \mathbf{1 b} / 130$ & $78: 22$ & LAY/880 & $\mathrm{VAC} / 2$ & 3 & $\mathbf{1 b}(16 \%)+\mathbf{2 a}, \mathbf{2 b}(82 \%, 91: 09)$ \\
\hline 5 & $\mathbf{3 a}, \mathbf{3 b} / 35$ & $44: 56$ & $\mathrm{LAY} / 65$ & $\mathrm{VAC} / 0.35$ & 3 & $\mathbf{3 b}(29 \%)+\mathbf{4 a}, \mathbf{4 b}(70 \%, 64: 36)$ \\
\hline 6 & $3 a, 3 b / 60$ & $44: 56$ & LAY/53 & VAC/0.6 & 1 & $\mathbf{3 b}(44 \%)+\mathbf{4 a}, \mathbf{4 b}(53 \%, 79: 21)$ \\
\hline 7 & $4 a, 4 b / 75$ & $50: 50$ & LAY/450 & OCT/0.2 & 4 & $\mathbf{3 a}, \mathbf{3 b}(61 \%, 75: 25)+\mathbf{4 a}, \mathbf{4 b}(37 \%, 09: 91)$ \\
\hline 8 & $\mathbf{5 a}, \mathbf{5 b} / 50$ & 89:11 & $\mathrm{N} 435 / 55$ & $\mathrm{VAC} / 0.35$ & 1 & $\mathbf{5 a}(87 \%)+\mathbf{6 b}(9 \%)$ \\
\hline 11 & $\mathbf{8 a}, 8 \mathbf{b} / 35$ & $76: 24$ & $\mathrm{LAY} / 400$ & OCT/0.08 & 7 & $\mathbf{8 a}, \mathbf{8 b}(98 \%, 76: 24)$ \\
\hline 12 & $9 a, 9 b / 110$ & $21: 79$ & $\mathrm{~N} 435 / 1434$ & $\mathrm{VAC} / 1.3$ & 5 & $9 \mathbf{a}(20 \%)+\mathbf{1 0 b}(76 \%)$ \\
\hline 13 & $\mathbf{9 a}, 9 \mathbf{b} / 90$ & $21: 79$ & $\mathrm{LAY} / 1040^{g}$ & $\mathrm{VAC} / 1$ & 14 & $\mathbf{9 a}, \mathbf{9 b}(74 \%, 19: 81)+\mathbf{1 0 a}, \mathbf{1 0 b}(24 \%, 32: 68)$ \\
\hline
\end{tabular}

${ }^{a}$ Reactions performed in toluene and shaken at $200 \mathrm{rpm}$ at $45{ }^{\circ} \mathrm{C} .{ }^{b}$ Calculated by ${ }^{1} \mathrm{H}$ NMR integration. ${ }^{c}$ Abbreviation for Novozym 435 : N435; and lipase AY: LAY. ${ }^{d}$ Abbreviation for vinyl acetate: VAC; and octanol: OCT. ${ }^{e}$ Isolated yield by flash chromatography; diastereomeric mixtures calculated by ${ }^{1} \mathrm{H}$ NMR integration. ${ }^{f}$ Obtained through the mild chemical deacylation hydrolysis using an excess of sodium carbonate in methanol of the epoxide mixture 8a,8b. ${ }^{g}$ Portionwise addition of lipase AY: $512 \mathrm{mg}$ each week.

hydroxyl group in ring $\mathrm{B}$ of the steroid (compounds $\mathbf{3}, \mathbf{4}, \mathbf{5}$, and 6) gives rise to the same effect. We have reported ${ }^{35}$ that moist MMPP (1.1 mmol per mmol of substrate) in dichloromethane at room temperature affords 5,6-epoxides with high stereoselectivity although with long reaction times. Nevertheless, 7-hydroxy derivatives had not been studied yet under such reaction conditions. $7 \beta$-Hydroxy-cholest-5-en-3-yl acetate (4) was submitted to moist $\mathrm{MMPP} / \mathrm{CH}_{2} \mathrm{Cl}_{2}$, at room temperature, and the result was a small amount of epoxide after 3 days, as assessed by TLC analysis. Therefore we made consecutive additions of MMPP ( $0.5 \mathrm{mmol}$ per mmol of substrate each 3 days) until complete substrate consumption. With this approach, an amount of $2.6 \mathrm{mmol}$ of MMPP for mmol of substrate was needed to complete the reaction in 12 days. The reaction gave an epoxide mixture of 56:44 $\alpha / \beta$ in $83 \%$ isolated yield (entry 4, Table 1). Applying the acetonitrile/reflux protocol, the reaction rate was significantly increased, being complete in 25 min and only a $10 \%$ excess addition of MMPP was required. The reaction afforded a 50:50 diastereomeric mixture of epoxides in a high yield (entry 5, Table 1). Summarizing, not only the reaction was much faster, as it has been high yielding with less oxidant requirement and with no significant difference in terms of stereoselectivity.

By exploring the reactivity of an homoallylic derivative of compound 4, the cholest-5-en-3 $\beta, 7 \beta$-diol (3), the same conclusions can be drawn. Moist $\mathrm{MMPP} / \mathrm{CH}_{2} \mathrm{Cl}_{2}$, added in a single portion ( $2.5 \mathrm{mmol}$ per mmol of substrate), at room temperature, the reaction needed 2 days to reach completion, producing an epoxide mixture of $\mathbf{3 a}, \mathbf{3 b}, 52: 48 \alpha / \beta$ ratio (entry 2 , Table 1). In reflux acetonitrile, the reaction was complete in $15 \mathrm{~min}$, rendering an epoxide mixture with a slight predominance of the $\beta$-epoxide (44:56 $\alpha / \beta$ ratio, entry 3 , Table 1 ).
It is also possible to verify that the faster the epoxidation reaction is, the bigger the amount of the hydroxyl syn-directed effect product is formed.

When a $7 \alpha$-hydroxyl substituent is present (compounds $\mathbf{5}$ and 6), the reaction outcome changes dramatically, with a predominance of the $\alpha$-epoxide (higher than $85 \%$ ), as expected (entries 6 and 7). The $\alpha$-epoxide formation was greater than in the case of cholesterol $\mathbf{1}$. The reaction rate was lower when compared to the epoxidation of the $7 \beta$-derivatives. Therefore, although some hydroxyl syn-directed effect can be observed, an additional $\alpha$-face blockage by the $7 \alpha$-hydroxyl is imposed to the peracid, hampering the reactivity.

Stereoselective Lipase Esterification of $\mathbf{3} \boldsymbol{\beta}$-Hydroxyepoxysterols. Steroidal epoxide mixtures, due to their close elution rates, are difficult to separate and isolate with good yields, even when highly stereoselective epoxidation methods are applied. A convenient approach to overcome such difficulty is the use of combined chemical and enzymatic procedures.

To obtain isomerically pure epoxysterols, we explored a biocatalytic approach developed by our group ${ }^{34}$ in which epimeric epoxides were separated by irreversible lipase catalyzed acylation in organic media. Specifically, Novozym 435 was able to convert in a stereoselective manner $5 \beta, 6 \beta$-epoxycholesterol (1b) into the corresponding $3 \beta$-acetate derivative, leaving unreacted the major isomer, the $\alpha$-epoxysteroid (1a). As a result, $5 \alpha, 6 \alpha$-epoxycholesterol (1a) and $5 \beta, 6 \beta$-epoxycholesteryl acetate (2b) were obtained in excellent isolated yields $(77 \%$ and $20 \%$, respectively) and $100 \%$ diastereomeric excess, as confirmed by ${ }^{1} \mathrm{H}$ NMR analysis (entry 1, Table 2).

Complementarily, when epimeric epoxysterols $\mathbf{1 a}$ and $\mathbf{1 b}$ were used as substrates for lipase AY catalyzed acylation, the $\alpha$-epoxide was the preferred substrate by the enzyme but some 
Scheme 3. Enzymatic Transesterification of 3 $\beta$-Hydroxy-5,6-epoxycholestanes

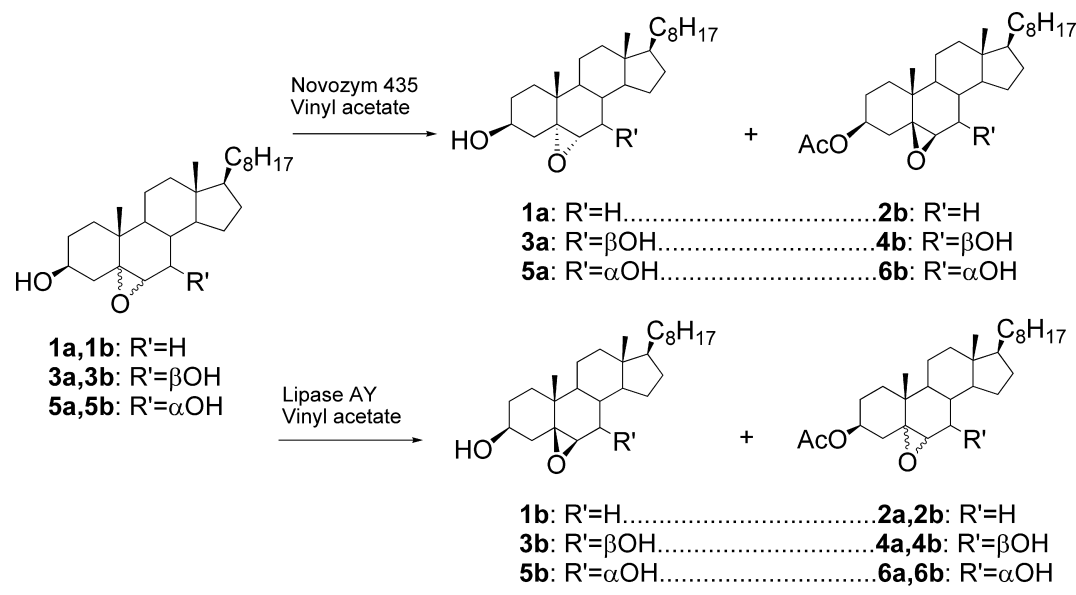

Scheme 4. Chemoenzymatic Discrimination of 4,5- and 5,6-Epoxycholestanes
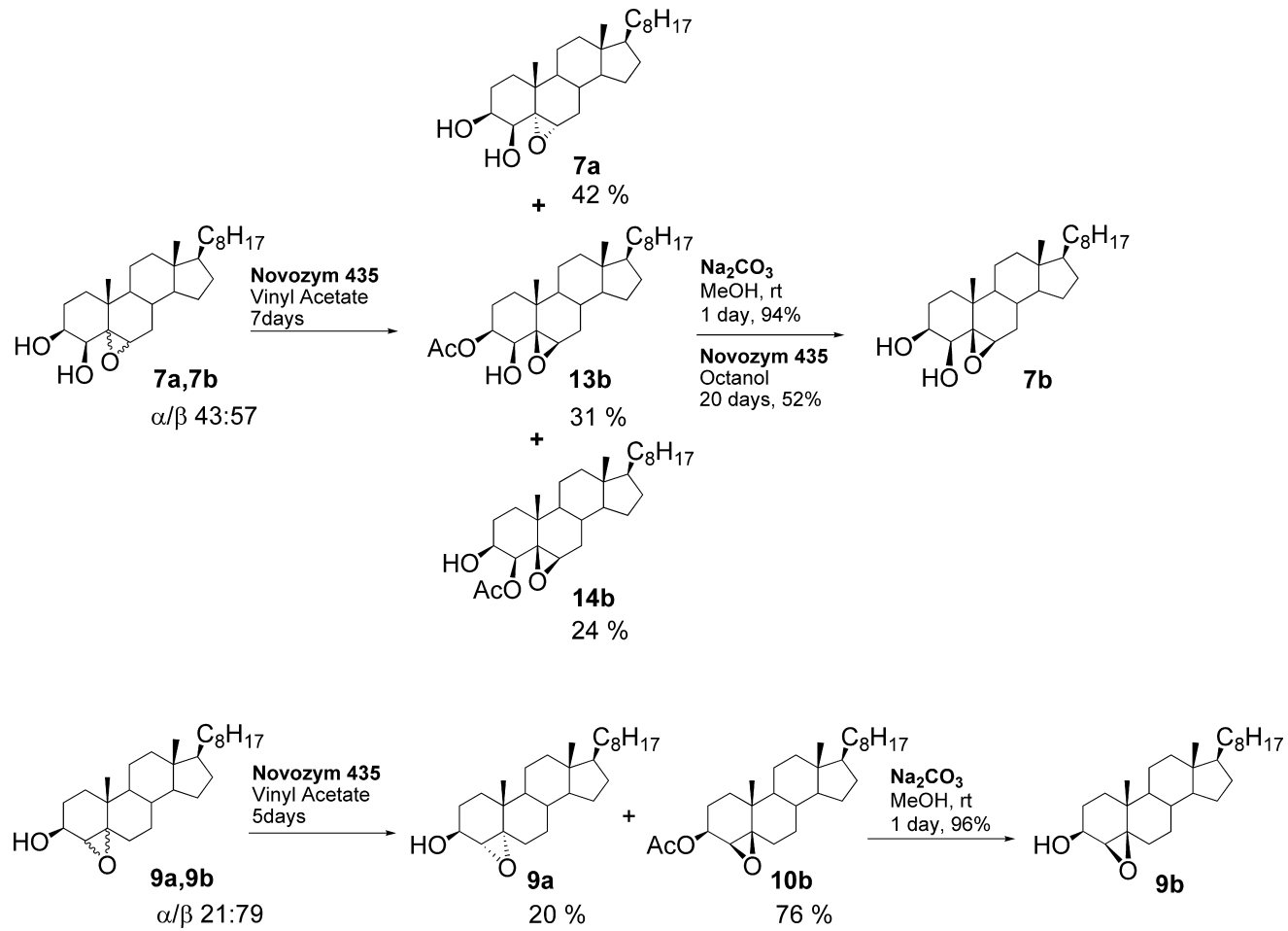

$\beta$-isomer was also acylated. Lipase AY proved to be less selective and reactive than Novozym 435. In fact, after 1 day, no diastereoselection could be achieved (entry 2, Table 2) and 3 days were needed to obtain $100 \%$ diastereomeric excess of the less reactive epimer $5 \beta, 6 \beta$-epoxycholesterol (1b) (entry 3 , Table 2).

In the presence of an additional $7 \beta$ - (compounds $\mathbf{3 a}$ and $\mathbf{3 b}$ ) or $7 \alpha$-hydroxyl group (compounds $\mathbf{5 a}$ and $\mathbf{5 b}$ ), Novozym 435 showed total regioselectivity for the $3 \beta$ position and the same stereoselectivity for acylating the $\beta$-epoxysteroid was observed (Scheme 3). 3 3 ,7-Dihydroxyl-5 $\alpha, 6 \alpha$-epoxy-cholestane derivatives (3a and 5a) and the corresponding $3 \beta$-acetoxy-5 $\beta, 6 \beta$-epoxy derivatives (4b and $\mathbf{6 b}$ ) were isolated in excellent yields and $100 \%$ diastereomeric excess (entries 4 and 8, Table 2).

On the other hand, the presence of a second hydroxyl group at C-4 provides different results using Novozym 435. As shown in Scheme 4, $3 \beta, 4 \beta$-dihydroxy-epoxysterols $7 \mathbf{a}$ and $\mathbf{7 b}$ were very slowly converted by Novozym 435 into a mixture of compounds. Clearly, Novozym was still selective for the acylation of the
$3 \beta$-OH in the $\beta$-epoxide. However, acylation at $4 \beta-\mathrm{OH}$ also occurred. After 7 days, the $5 \alpha, 6 \alpha$-epoxy-diol (7a), the $3 \beta$ acetoxy-5 $\beta, 6 \beta$-epoxy derivative (13b), and the $4 \beta$-acetoxy$5 \beta, 6 \beta$-epoxy derivative (14b) were recovered isomerically pure by flash chromatography (entry 9 , Table 2).

We have previously reported the lipase-catalyzed acylation of 2,3- and 3,4-vicinal diols of steroids. ${ }^{47} 3 \beta, 4 \beta$-Dihydroxysteroids were used as substrates for a panel of enzymes and, although Candida rugosa lipase and lipase AY were the best enzymes, Novozym 435 also accepted the diol. Herein, the presence of an additional 5,6-epoxy group hinders the access to Candida rugosa lipase and lipase AY active sites. The results obtained with Novozym 435 agree with our previous results: preference for the $3 \beta-\mathrm{OH}$ instead of $4 \beta-\mathrm{OH}^{47}$ and preference for the $\beta$-epoxide. ${ }^{34}$ However, the presence of other functional groups close to the $3 \beta-\mathrm{OH}$ nucleophile renders the reaction slower.

Using lipase AY as catalyst, we studied the acylation of an epimeric mixture of 5,6-epoxycholestane- $3 \beta, 7 \beta$-diol (3a,3b 44 : 
Table 3. Mild Enzymatic Alcoholysis and Transesterifications of 5,6-Epoxycholestanes ${ }^{a}$

\begin{tabular}{|c|c|c|c|c|c|}
\hline entry & substrate $(\mathrm{mg})$ & enzyme (mg) & reagent $(\mathrm{mL})$ & time & product $^{b}$ \\
\hline 1 & $1 a / 30$ & lipase AY/60 & vinyl acetate/0.3 & 2 days & 2a $(94 \%)$ \\
\hline 2 & $4 b / 50$ & Novozym 435/30 & octanol/0.15 & 20 days & $3 \mathbf{b}(56 \%)$ \\
\hline 3 & $\mathbf{6 a} / 40$ & lipase AY/400 & octanol/0.15 & 4 days & $5 a(94 \%)$ \\
\hline 5 & $12 a / 45$ & lipase AY/450 & octanol/0.15 & 3 days & 11a $(96 \%)$ \\
\hline 6 & $13 \mathrm{~b} / 30$ & Novozym 435/90 & octanol/0.1 & 20 days & $7 \mathbf{b}(52 \%)$ \\
\hline
\end{tabular}

${ }^{a}$ Reactions performed in toluene and shaken at $200 \mathrm{rpm}$ at $45^{\circ} \mathrm{C} .{ }^{b}$ Isolated yield by flash chromatography.

56). After 3 days, complete conversion of the $\alpha$-epoxy derivative was observed. However, by TLC control, the reaction seemed to be running faster than the one for 5,6-epoxycholesterols, 1a,1b. In fact, after 3 days, $5 \beta, 6 \beta$-epoxycholestane- $3 \beta, 7 \beta$-diol (3b) was successfully isolated isomerically pure, but in a low yield (29\%), due to the acylation of the $\beta$-epimer along with the $\alpha$ (entry 5, Table 2). Consequently, we repeated the reaction using a lesser amount of enzyme and left it running for only one day (entry 6, Table 2). This procedure resulted in a great increase in the amount of the $\beta$-epoxide derivative isolated $(44 \%)$.

Then we studied the lipase AY acylation of epoxide mixtures with an additional $\beta$-allylic hydroxyl substituent in ring A. A mixture of 5,6-epoxycholestane-3 $\beta, 4 \beta$-diol (7a,7b 76:24) was separated using the same amount ratio of lipase AY found to obtain a good percentage recovery of the $5 \beta, 6 \beta$-epoxycholestane- $3 \beta, 7 \beta$-diol (3b) in one day. In effect, isolation of $10 \%$ pure $5 \beta, 6 \beta$-epoxycholestane- $3 \beta, 4 \beta$-diol was achieved after 1 day of reaction (entry 10, Table 2).

Because of the close proximity of the epoxide and the nucleophile for enzyme acylation, ring A epoxysterols constitute interesting substrates to perform such enzymatic reactions. We intended to evaluate the ability of both enzymes to acylate the $3 \beta$-hydroxyl group when a neighboring 4,5 -epoxy functionality is present. Although the isomeric $4 \alpha, 5 \alpha$ - and $4 \beta, 5 \beta$-epoxy$3 \beta$-hydroxysterols $\mathbf{9 a}$ and $\mathbf{9 b}$ were distinguished by Novozym 435 , which again showed preference for the acylation of $\beta$-epoxide (entry 12, Table 2), lipase AY revealed to be inefficient, with practically no stereoselectivity and low reactivity (entry 12, Table 2). Comparing to the 5,6-epoxysterols 1a and $\mathbf{1 b}$, the presence of the epoxide in the 4,5-position hinders the access of the nucleophilic $\mathrm{C} 3-\mathrm{OH}$ to the acyl enzyme, resulting in longer reaction times (entries 1 and 12; 3 and 13, Table 2).

Finally, we decided to investigate the acylation of $5 \alpha, 6 \alpha-$ epoxy-7-norcholestan-3 $\beta$-ol (11a) by lipase AY. Comparing to $5 \alpha, 6 \alpha$-epoxycholesterol (1a), the 5-membered B-ring of 11a has a positive effect on the reaction rate (entries 1 and 5, Table 3 ), and after one day of reaction, 12a was isolated in $97 \%$.

Lipase Catalyzed Deacetylation of $3 \beta$-Acetoxy-epoxysterols. Lipase catalyzed deacetylation of $3 \beta$-acetoxy-epoxysterols was explored using $n$-octanol as nucleophile. The deacylation of pure $\mathbf{4 b}, \mathbf{8 b}$, and $10 \mathbf{b}$ was pursued using Novozym 435 catalyzed alcoholysis in toluene. The respective epoxyalcohols $\mathbf{3 b}, \mathbf{7 b}$ were obtained in low isolated yields (about $50 \%$, entries 2 and 4 , Table 3 ) after a long reaction time (20 days). $4 \beta, 5 \beta$-Epoxycholestan- $3 \beta$-ol (9b) was difficult to separate by flash chromatography from $n$-octanol. Thus we used another acyl acceptor, $n$-pentanol, which can be eliminated by vacuum, but the reaction rate was even lower. For this reason, we adopted a mild chemical hydrolysis procedure using sodium carbonate in methanol for the synthesis of $\mathbf{9 b}$, which was successfully isolated in $96 \%$ yield after $24 \mathrm{~h}$ of reaction.

On the other hand, lipase AY proved to be efficient in the alcoholysis of $7 \alpha$-hydroxy- $5 \alpha, 6 \alpha$-epoxycholestan- $3 \beta$-yl-acetate (6a) and $5 \alpha, 6 \alpha$-epoxy-7-norcholestan- $3 \beta$-yl-acetate (12a), affording quantitative hydrolysis in 4 and 3 days, respectively (entries 3 and 6, Table 3).

Stereoselective deacylation of $3 \beta$-acetoxy-5,6-epoxysteroids was already achieved with the use of lipase AY and octanol as acyl acceptor, exploring its $\alpha$-stereopreference in epoxide mixtures where the $\alpha$-epoxide was the minor epimer. Three days were needed to isolate the corresponding $3 \beta$-acetoxy- $5 \beta, 6 \beta$ epoxy-derivatives in $100 \%$ diastereomeric excess. ${ }^{34} \mathrm{We}$ have explored lipase AY's ability to discriminate acetoxy-epoxy mixtures by selective alcoholysis of $3 \beta$-acetoxy-5,6-epoxysteroids containing an allylic 7-hydroxyl substituent. As mentioned above, we had noticed that alcoholysis of $7 \alpha$-hydroxy$5 \alpha, 6 \alpha$-epoxycholestan- $3 \beta$-yl-acetate (6a) was quantitative in 4 days. To perform the stereoselective deacylation of $7 \beta$-hydroxy5,6-epoxy-cholesteryl-3 $\beta$-acetate mixture $(\mathbf{4 a}, \mathbf{4 b}, 50: 50)$, we used a 12-fold amount of the lipase and stopped the reaction in 4 days (entry 7, Table 2). Although the TLC analysis of the reaction suggested a successful separation of the pure $\mathbf{4 b}$ compound by complete deacylation of the $\alpha$-epimer $\mathbf{4 a},{ }^{1} \mathrm{H}$ NMR of the two isolated fractions proved that complete diastereoselectivity was not achieved and longer time would be needed. Moreover significant deacylation of the $\beta$-epimer is observed, which makes lipase AY not suitable for high yielding epoxide diastereoselection.

In addition, lipase AY did not deacylate a mixture of 5,6epoxycholestane-3 $\beta, 4 \beta$-diyl-diacetates (10a,b) (entry 11, Table 2 , Scheme 5) due to the steric hindrance imposed by the two bulky acetate substituents.

Biological Evaluation. Taking advantage of the chemoenzymatic approach described above, several isomerically pure epoxycholestanes were prepared. Compound purity was controlled by gas chromatography and proved to be $>95 \%$ for all compounds, except for $5 \beta, 6 \beta$-epoxycholestane- $3 \beta, 4 \beta$-diol (7b), which undergoes thermal degradation in the conditions used for analysis.

The evaluation of the cytotoxicity was performed on the sterol starting materials, compounds $\mathbf{1}, \mathbf{3}, \mathbf{4}, \mathbf{5}$, and $\mathbf{7}$ and the corresponding epoxysteroids $\mathbf{1 a}, \mathbf{1 b}, \mathbf{3 a}, \mathbf{3 b}, \mathbf{5 a}, \mathbf{7 a}, \mathbf{7 b}, \mathbf{1 1}, \mathbf{1 0 a}$, 10b, 11a, 13b, and 14b. Cytotoxicity was evaluated by the Alamar Blue assay based on the cellular reduction of the blue resazurin to the pink resorufin by the living cells. ${ }^{48,49}$

The in vitro cell toxicity effects mediated by the different synthesized compounds were studied on HT29 (human colon adenocarcinoma; adherent epithelial cell line) and LAMA-84 (human chronic myeloid leukemia in blast crisis; suspended/ slowly adherent cell line) cancer cell lines, as well as on noncancer cells BJ (human foreskin fibroblast; adherent cell line). Compounds were primarily screened in the HT29 cancer cell line due to the straight relation of sterols and colon tissues, where cholesterol is both absorbed and synthesized. ${ }^{50,51}$ The compounds exhibiting higher cytotoxic effects were further tested in the other cells. 
Scheme 5. Enzymatic Alcoholysis of 3 $\beta$-Acetoxy-5,6-epoxycholestanes

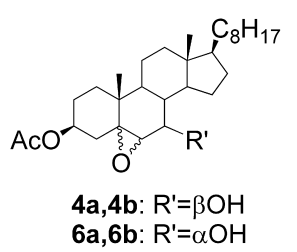

6a,6b: $\mathrm{R}^{\prime}=\alpha \mathrm{OH}$

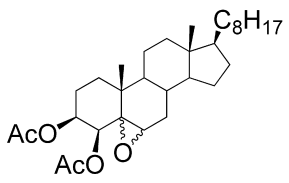

Lipase AY Octanol $\mathrm{X}$
Table 4. Cytotoxicity of the Compounds Synthesized $\left(\mathrm{IC}_{50}{ }^{a}\right.$ in $\left.\mu \mathrm{M}\right)$, in Three Human Cell Lines after $48 \mathrm{~h}$ of Exposure

\begin{tabular}{cllll}
\hline entry & compound & HT29 & LAMA-84 & BJ \\
\hline 1 & $\mathbf{1}$ & $>50$ & & \\
2 & $\mathbf{1 a}$ & $>50$ & & \\
3 & $\mathbf{1 b}$ & 37.6 & & \\
4 & $\mathbf{3}$ & 6.4 & 4.8 & 13.4 \\
5 & $\mathbf{3 a}$ & 13.3 & 4.1 & 19.5 \\
6 & $\mathbf{3 b}$ & 8.3 & 7.0 & \\
7 & $\mathbf{4}$ & 29.4 & & \\
8 & $\mathbf{5}$ & 15.5 & & \\
9 & $\mathbf{5 a}$ & 33.8 & & \\
10 & $\mathbf{7}$ & $>50$ & & \\
11 & $\mathbf{7 a}$ & 38.2 & & \\
12 & $\mathbf{7 b}$ & 17.7 & 8.0 & \\
13 & $\mathbf{9}$ & $>50$ & & \\
14 & $\mathbf{9 a}$ & 61.9 & & \\
15 & $\mathbf{9 b}$ & 22.6 & 11.2 & \\
16 & $\mathbf{1 1 a}$ & 40.9 & & \\
17 & $\mathbf{1 3 b}$ & 28.2 & & \\
18 & $\mathbf{1 4 b}$ & 15.9 & & \\
19 & cisplatin & 21.9 & 9.1 & \\
20 & doxorubicin & 1.15 & 0.76 & \\
\hline
\end{tabular}

${ }^{a} \mathrm{IC}_{50}$, the concentration that inhibits $50 \%$ of cellular growth. Data are presented as the mean of at least three separate experiments for each cell line.

As shown in Table 4, the compounds exhibited different degrees of cytotoxicity toward the cell lines tested. The oxysterols synthesized induce higher cytotoxicity in the LAMA84 cell line as compared to HT29 cells, as displayed in Figure 1. The selectivity was studied by incubating the compounds with both cancer (HT29 and LAMA-84) and noncancer cell lines (BJ) and, generally, they are more cytotoxic toward cancer cell lines than normal cells, except compound $\mathbf{3 a}$, which exhibited similar effects on both HT29 and BJ cells (Table 4, entry 5 and Figure 1b).

The introduction of an epoxy moiety in the steroid nucleus led to different results. In the case of nonsubstituted ring $\mathrm{B} \Delta^{4}$ and $\Delta^{5}$-cholestenes, the epoxidation of the molecules leads, in general, to increased cytotoxicity. Indeed, epoxides 1b, 11a, and $\mathbf{1 1 b}$ are cytotoxic, whereas the corresponding olefins $\mathbf{1}$ and $\mathbf{1 1}$ are not cytotoxic, although epoxide 1a is also not cytotoxic. However, when a hydroxyl group is present in position C-7 (compounds $\mathbf{3}$ and 5), the introduction of the epoxy moiety decreases activity (compounds $\mathbf{3 a}, \mathbf{3 b}$, and $\mathbf{5 a}$ ).

The stereoisomery of the epoxides is important for bioactivity. $\beta$-Epoxides $\mathbf{1 b}, \mathbf{7 b}$, and $\mathbf{9 b}$ are more active than the corresponding $\alpha$-epoxides 1a, 7a, and 9a. The exceptions are the epoxides 3a and 3b. Although the $\beta$-epoxide $\mathbf{3 b}$ is more active than $\mathbf{3 a}$ on HT29 cells, less activity toward LAMA-84 and BJ was observed.

The results indicate that the presence of a second hydroxyl group at position $\mathrm{C}-7$ has an impact on bioactivity. While cholesterol $\mathbf{1}$ is not cytotoxic, its $7 \beta-\mathrm{OH}$ and $7 \alpha-\mathrm{OH}$ derivatives are cytotoxic (compounds $\mathbf{3}$ and $\mathbf{5}$, respectively). In the presence of the epoxide group, the cytotoxicity also increases with the addition of a hydroxyl at C-7. As shown in Table 4, the $\alpha$-epoxides $5 \mathbf{a}$ (with a $7 \alpha-\mathrm{OH}$ group) and 3a (with a $7 \beta-\mathrm{OH}$ group) are more cytotoxic than epoxycholesterol 1a. Moreover, the $\beta$-epoxide $\mathbf{3 b}$ is 4.5 -fold more cytotoxic than compound $\mathbf{1 b}$.

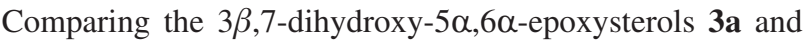
$\mathbf{5 a}$, the stereochemistry of the hydroxyl group at C-7 influences the activity, the $7 \beta$-OH derivative $3 \mathbf{a}$ being almost 3 -fold more cytotoxic in the HT29 cell line.

On the other hand, the comparison of $4 \beta$-hydroxy- $5 \beta, 6 \beta$ epoxycholesterol $\mathbf{7 b}$ with its derivative $\mathbf{1 4 b}$ clearly indicate that the presence of the $4 \beta$-acetate does not affect significantly the activity toward these cell lines. However, the protection of the $3 \beta$-hydroxyl group with an acetate, $\mathbf{1 3 b}$, leads to a significant decrease in cytotoxicity. The same conclusion can be drawn when comparing the oxysterols $\mathbf{3}$ and $\mathbf{4}$, where again the introduction of the acetate substituent in position C-3 does not favor cytotoxicity.

The presence of an additional $4 \beta$-hydroxy group in the cholesterol structure does not confer cytotoxicity (compound 7). However, the $\alpha$ - and $\beta$-epoxy derivatives of 7 are cytotoxic (compounds $7 \mathbf{a}$ and $\mathbf{7 b}$ ). Nonetheless, the $4 \beta$-hydroxy group has a lower effect in the cytotoxicity of the epoxysterols as compared to the $7 \alpha$ - and $7 \beta$-hydroxy derivatives.

The position of the epoxide in the steroid nucleus also has an impact on the cytotoxicity, $9 \mathbf{b}$ (a $4 \beta, 5 \beta$-epoxide) being more active than $\mathbf{1 b}$ (a $5 \beta, 6 \beta$-epoxide) in the HT29 cell line. However, compounds $9 \mathbf{a}$ and $\mathbf{1 a}$, both $\alpha$-epoxides at 4,5- and 5,6-positions, respectively, have comparable low toxicities.

Finally, comparing the influence of the ring B size, the $\alpha$-epoxide functionality seems to be more favorable in a fivemembered ring, as shown in Table 4. Compound 11a is more cytotoxic than $\mathbf{1 a}$ and proximally cytotoxic to $\mathbf{1 b}$.

A brief and schematic representation of these structure-activity relations for cytotoxicity is presented in Figure 2.

Cisplatin and doxorubicin are two of the most effective chemotherapeutic agents used nowadays for the treatment of a broad range of cancers ${ }^{52}$ and were used as reference drugs for the cytotoxic evaluation. Our results indicate that LAMA-84 cells are more sensitive to these drugs as compared to HT29 or 


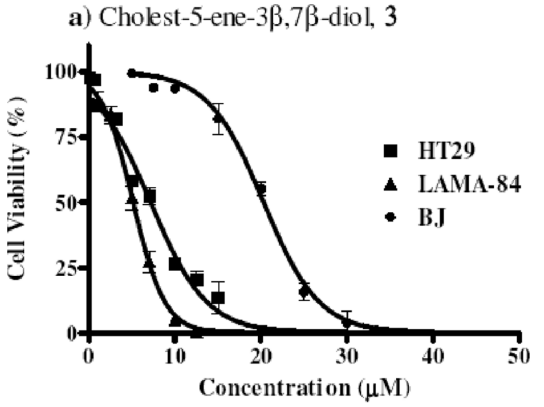

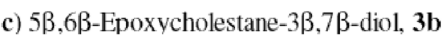

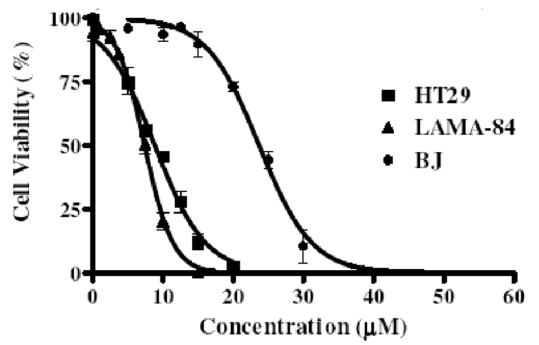

b) $5 \alpha, 6 \alpha$-Epoxycholestane-3 $3,7 \beta$-diol, $3 \mathrm{a}$

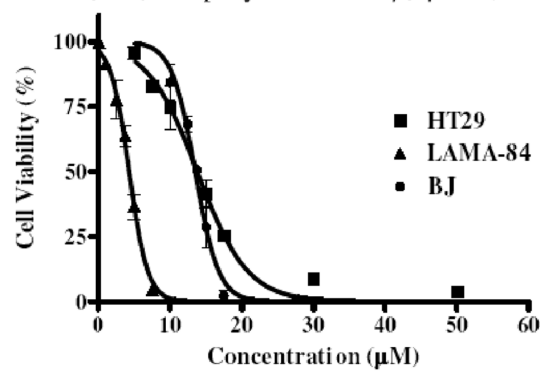

d) $4 \beta, 5 \beta$-Epoxycholestan-3 3 -ol, $9 \mathrm{~b}$

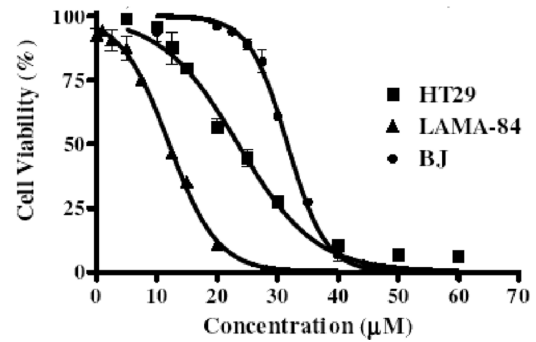

Figure 1. Dose-dependent effect of oxysterols $(\mathbf{3}, \mathbf{3 a}, \mathbf{3 b}, \mathbf{9 b})$ on cell viability of different cell lines (cancer: HT29, LAMA-84, and noncancer: $\mathrm{BJ})$. Data shown are mean \pm standard error of at least three independent experiments.

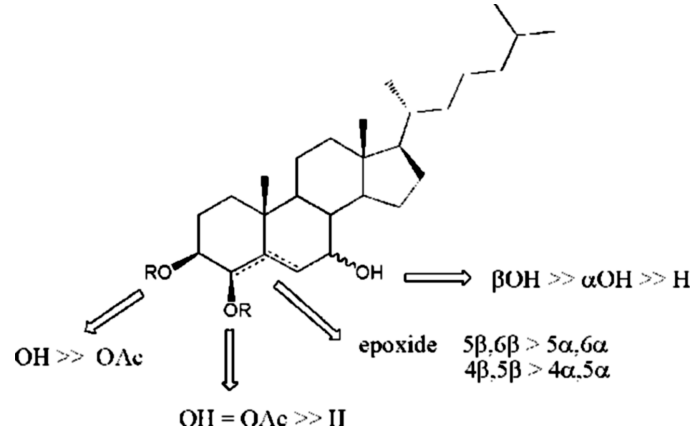

Figure 2. Graphical depiction of the SAR for cell cytotoxicity based on the $\mathrm{IC}_{50}$ results.

BJ cells and as is the case for the oxysterol compounds synthesized. In fact, cisplatin has a similar cytotoxic potency for both HT29 and BJ cells, besides colorectal carcinomas, one of the leading causes of cancer-related deaths in U.S., ${ }^{53}$ are known to be resistant to chemotherapy, namely involving cisplatin or even doxorubicin because they generally express high levels of the MDR1 gene that encodes the P-glycoprotein (Pgp) responsible for the extracellularly drug transportation. ${ }^{54}$ Thus oxysterols $\mathbf{3}, \mathbf{3 b}, \mathbf{7 b}$, and $\mathbf{9 b}$ constitute a group of compounds with interesting cytotoxic properties due to their higher activity on cancer cells. Moreover, compounds $\mathbf{3}$ and 3b showed a better cytotoxic profile than cisplatin for all cells tested.

\section{Conclusion}

Oxysterols have become increasingly recognized as bioactive compounds and much work has been done in order to identify cellular receptors for oxysterols and to correlate them with novel in vivo functions. ${ }^{4}$

Oxysterols can be generated endogenously by simple autoxidation of cholesterol or by enzymatic reactions involving specific hydroxylases, and it is postulated that the actions of these compounds are mediated by oxysterol binding proteins. ${ }^{55}$ Therefore, could not oxysterols and their epoxy derivatives be important local regulators of cell growth and/or death in vivo?
In fact, cholesterol is highly abundant in humans and shows no cytotoxicity. However, a simple oxidation can transform cholesterol into a cytotoxic molecule, $\mathbf{1 b}$, and the same for the conversion of $4 \beta$-hydroxycholesterol, 7 , one of the most abundant oxysterols in humans, into $\mathbf{7 b}$.

The synthesis of oxysterols involves a panel of chemical reactions, mainly oxidative. A recent methodology developed by us to access epoxysteroids in a fast and straightforward manner ${ }^{35}$ was further investigated herein.

The biocatalytic acylation/deacylation at the position C-3 of $5 \alpha, 6 \alpha$ - and $5 \beta, 6 \beta$-epoxysterols was previously reported by our group. ${ }^{34}$ This biocatalytic approach was extended and has found a useful application to obtain pure bioactive sterols. The stereoselective enzymatic acylation of $4 \alpha, 5 \alpha$ - and $4 \beta, 5 \beta$-epoxy$3 \beta$-hydroxysteroids has been studied for the first time. Furthermore, the stereo- and regioselective acylation of dihydroxyepoxysterols was explored, disclosing the ability of the lipases tested to act on the $3 \beta$-position of steroids with striking regioselectivity by leaving unreacted the C-7 hydroxyl groups. Novozym 435 was shown to be the ideal enzyme to perform the stereoselective discrimination of several epoxysterols by acylating the $\beta$-epoxy isomer.

The bioactivity of the epoxysterols obtained was studied by evaluating their cytotoxic potential in two cancer cell lines and in a noncancer cell line. The results obtained show that these molecules are cytotoxic in a dose-dependent manner at micromolar range and have higher activity on the tumor cells (Table 4; Figure 1), being the bioactivity strongly affected by the stereochemistry of the 4,5- and 5,6-epoxide and the surrounding hydroxyl groups at 3-, 4- and 7-positions (Figure 2).

$7 \beta$-Hydroxycholesterol (3) is a widely studied oxysterol, mainly due to its possible involvement in the atherosclerosis process. Indeed, $7 \beta$-hydroxycholesterol is one of the main cytotoxic oxysterols present in oxidized LDL, foam cells, and fatty streaks. ${ }^{56}$ Moreover and among the oxysterols studied, $7 \beta$ hydroxycholesterol is known to be one of the most potent inducers of cell death in cultured cell lines, ${ }^{57,58}$ which are normally related to the apoptotic pathway. ${ }^{59,60}$ Our results corroborate the reported cytotoxic activity of $7 \beta$-hydroxycho- 
lesterol. ${ }^{58}$ In addition, we show that this oxysterol is more active toward tumor cell lines than to the normal cell line BJ.

Recent studies describe the cytotoxicity of epoxysteroids such as $5 \alpha, 6 \alpha$-epoxycholesterol (1a) ${ }^{61}$ and $5 \beta, 6 \beta$-epoxycholesterol (1b) ${ }^{62}$ and the potential of induction of apoptotic cell death. ${ }^{63}$ Nonetheless, there are no reports on the biological activities of synthetic epoxy derivatives of the common oxysterols such as $4 \beta$-hydroxycholesterol and $7 \alpha$ - or $7 \beta$-hydroxycholesterol.

In summary, we describe herein an efficient chemoenzymatic methodology for the preparation of isomerically pure epoxysterols. A recent protocol using MMPP allowed the efficient synthesis of a library of epoxysterols. The biocatalytic discrimination of the resulting epimeric epoxysterols gave access to pure isomers through mild and efficient lipase-catalyzed acylations and deacylations. From the library synthesized $5 \beta, 6 \beta$-epoxycholestane- $3 \beta, 7 \beta$-diol, $\mathbf{3 b}$ revealed to be the most cytotoxic and to display higher activity toward tumor cells. In fact, compounds 3b and $\mathbf{3}$ exhibited very similar cytotoxic and selectivity behavior as it can be observed in the curve of the dose-dependent effect on cell viability (Figure 1), suggesting that both compounds share the same mechanism responsible for cell death in the cell lines tested. To the best of our knowledge, the cytotoxicity of compound $\mathbf{3 b}$ had not been studied before.

The cytotoxic evaluation of several epoxy derivatives revealed structure-activity relationships for this type of sterols as summarized briefly in Figure 2.

\section{Experimental Section}

Chemistry. General Methods. Cholesteryl acetate, cholesterol, and cholestenone were purchased from Sigma-Aldrich Co. The other starting materials were prepared as reported in literature ${ }^{35}$ and as described below in the following sections. All reagents and solvents were purchased from Sigma-Aldrich Co. All commercial available chemicals were used without purification. Lipase AY and Novozym 435 were obtained from Amano and Sigma, respectively. Enzymatic reactions were performed in a New Brunswick Scientific C24 Incubator Shaker. TLC monitoring was done using Kieselgel $60 \mathrm{HF}_{254} /$ Kieselgel $60 \mathrm{G}$ and revealed with Komarowsky's reagent. ${ }^{64}$ Flash column chromatography was performed in a Büchi automated system using a Borosilikat 3.3 column and silica gel 60 (230-400 mesh ASTM). Melting points were determined on a Büchi melting point B-540 and are uncorrected. IR spectroscopy was performed on a Jasco FT/IR 420 spectrophotometer. ${ }^{1} \mathrm{H},{ }^{13} \mathrm{C}$, and DEPT NMR spectra were recorded on Bruker Avance $300 \mathrm{MHz}$ and $500 \mathrm{MHz}$. Mass spectra were recorded on a Thermo Finnigan mass spectrometer, model LCQ Advantage MAX. The degree of the epoxysteroids purity was controlled by gas chromatography carried out on an Agilent Technologies 6850 Network GC system using an Agilent 19091Z-41 3E HP-1 methyl siloxane capillary $(30.0 \mathrm{~m} \times 320 \mu \mathrm{m}$ $\times 0.25 \mu \mathrm{m})$ and with a flux mixture of $\mathrm{H}_{2}(40 \mathrm{~mL} / \mathrm{min}), \mathrm{N}_{2}(45$ $\mathrm{mL} / \mathrm{min})$, and air $(450 \mathrm{~mL} / \mathrm{min})$. Compounds were dissolved in chloroform for injection. Elution run started in $100{ }^{\circ} \mathrm{C}$ for one min and increased $35^{\circ} \mathrm{C} / \mathrm{min}$ until $300{ }^{\circ} \mathrm{C}$. Retention times of the epoxy compounds were between 10 and $15 \mathrm{~min}$. Purity was confirmed to be $>95 \%$ for all compounds, except for $5 \beta, 6 \beta$-epoxycholestane$3 \beta, 4 \beta$-diol (7b), which undergoes thermal degradation in the conditions used for analysis. High resolution electrospray mass spectra (HR ESI-MS) were acquired with a Fourier transfer ion cyclotron resonance (FT-ICR) APEX II model (Bruker Daltonics) equipped with a $4.7 \mathrm{~T}$ cryomagnet (Magnex). Samples were dissolved in the specific solvent and injected into the instrument equipped with its own ESI source. Spectra were recorded in the HR mode with resolutions ranging from 20000 to 30000 .

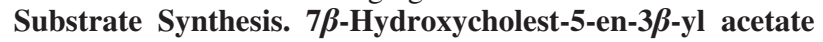
(4). To a mixture of cholesteryl acetate $(1950 \mathrm{mg}, 4.549 \mathrm{mmol})$ and copper iodide $(520 \mathrm{mg}, 2.729 \mathrm{mmol})$ in $\mathrm{CH}_{3} \mathrm{CN}(30 \mathrm{~mL})$ at reflux temperature was added portionwised $t$-butyl hydroperoxide (70\% wt soln) $(5 \times 1.171 \mathrm{~mL}$ each $45 \mathrm{~min}, 45.49 \mathrm{mmol})$. After last addition, the reaction mixture was stirred at reflux temperature for another $1 \mathrm{~h}$. Then reaction solvent was concentrated under vacuum and the residue dissolved in diethyl ether and filtered under celite to eliminate the copper iodide. Organic phase was left stirring with $\mathrm{Na}_{2} \mathrm{SO}_{3}$ (10\% aq soln) for $2 \mathrm{~h}$ and then extracted with diethyl ether. The resulting organic phase was washed with $\mathrm{NaHCO}_{3}$ (sat. aq soln) and water, dried over anhydrous $\mathrm{Na}_{2} \mathrm{SO}_{4}$, and concentrated under vacuum. 7-oxo-Cholest-5-en-3 $\beta$-yl acetate $(1027 \mathrm{mg}, 51 \%)$ was isolated using column chromatography (petroleum ether, ethyl acetate 10:1) IR (film) 3024, 2953, 2867, 1734, 1669, 1471, 1373, 1268, 1239, 1041, $751 \mathrm{~cm}^{-1}$. ${ }^{1} \mathrm{H}$ NMR $\left(300 \mathrm{MHz}, \mathrm{CDCl}_{3}\right) \mathrm{ppm}$ $0.68\left(3 \mathrm{H}, \mathrm{s}, 18-\mathrm{CH}_{3}\right), 0.86$ and 0.87 (each $3 \mathrm{H}, 2 \mathrm{~d}, J=6.6 \mathrm{~Hz}$, $26-\mathrm{CH}_{3}$ and $\left.27-\mathrm{CH}_{3}\right), 0.92\left(3 \mathrm{H}, \mathrm{d}, J=6.6 \mathrm{~Hz}, 21-\mathrm{CH}_{3}\right), 1.21(3 \mathrm{H}$, s, $\left.19-\mathrm{CH}_{3}\right), 2.05\left(3 \mathrm{H}, \mathrm{s}, 3 \beta-\mathrm{CH}_{3} \mathrm{COO}\right), 4.72(1 \mathrm{H}, \mathrm{ddt}, J=11.5$, $11.5,5.4,4.4 \mathrm{~Hz}, 3 \alpha-\mathrm{H}), 5.70(1 \mathrm{H}, \mathrm{d}, J=1.7 \mathrm{~Hz}, 6-\mathrm{H}) .{ }^{13} \mathrm{C} \mathrm{NMR}$ (75 MHz, $\left.\mathrm{CDCl}_{3}\right)$ ppm 11.9, 17.2, 18.8, $21.1\left(\mathrm{CH}_{2}\right), 21.2,22.5$, 22.8, $23.7\left(\mathrm{CH}_{2}\right), 26.2\left(\mathrm{CH}_{2}\right), 27.3\left(\mathrm{CH}_{2}\right), 27.9,28.5\left(\mathrm{CH}_{2}\right), 35.7$, $35.9\left(\mathrm{CH}_{2}\right), 36.1\left(\mathrm{CH}_{2}\right), 37.7\left(\mathrm{CH}_{2}\right), 38.2(\mathrm{C}-10), 38.6\left(\mathrm{CH}_{2}\right), 39.4$ $\left(\mathrm{CH}_{2}\right), 43.0$ (C-13), 45.3, 49.7, 49.9, 54.7, 72.1, 126.6 (C-6), 163.8 (C-5), $170.2\left(\mathrm{CH}_{3} \mathrm{COO}\right), 201.9(\mathrm{C}-7)$. Then, to a solution of 7-oxocholest-5-en-3 $\beta$-yl acetate $(677 \mathrm{mg} ; 1.529 \mathrm{mmol})$ in THF $(8 \mathrm{~mL})$ and $\mathrm{MeOH}(4 \mathrm{~mL})$ containing $\mathrm{CeCl}_{3} \cdot 7 \mathrm{H}_{2} \mathrm{O}(575.8 \mathrm{mg} ; 1.529 \mathrm{mmol})$ was added $\mathrm{NaBH}_{4}(144.6 \mathrm{mg} ; 3.822 \mathrm{mmol})$. The mixture was stirred at $\mathrm{rt}$ for $15 \mathrm{~min}$ and concentrated under vacuum. The residue was dissolved in diethyl ether, washed sequentially with $\mathrm{HCl}(5 \%$ aq soln $), \mathrm{NaHCO}_{3}(10 \%$ aq soln) and water, dried over anhydrous $\mathrm{MgSO}_{4}$, filtered, and evaporated to yield the $7 \beta$-hydroxycholest5 -en-3 $\beta$-yl acetate, 4 product. Flash chromatography (petroleum ether, ethyl acetate $2: 1)$ afforded the pure compound $(650 \mathrm{mg} ; 96 \%)$ $\mathrm{mp} 110-111^{\circ} \mathrm{C}(\mathrm{EtOH})$; lit. ${ }^{65} 109-110^{\circ} \mathrm{C}$. IR (film) 3326, 2948, $2872,1734,1471,1379,1245,1036,757 \mathrm{~cm}^{-1}$. ${ }^{1} \mathrm{H}$ NMR $(300$ $\left.\mathrm{MHz}, \mathrm{CDCl}_{3}\right) \mathrm{ppm} 0.69\left(3 \mathrm{H}, \mathrm{s}, \mathrm{CH}_{3}-18\right), 0.86$ and 0.87 (each $3 \mathrm{H}$, $2 \mathrm{~d}, J=6.6 \mathrm{~Hz}, 26-\mathrm{CH}_{3}$ and $\left.27-\mathrm{CH}_{3}\right), 0.92(3 \mathrm{H}, \mathrm{d}, J=6.6 \mathrm{~Hz}$, $\left.21-\mathrm{CH}_{3}\right), 1.06\left(3 \mathrm{H}, \mathrm{s}, 19-\mathrm{CH}_{3}\right), 2.04\left(3 \mathrm{H}, \mathrm{s}, 3 \beta-\mathrm{CH}_{3} \mathrm{COO}\right), 3.86$ $(1 \mathrm{H}, \mathrm{td}, J=7.9,2.0,2.0 \mathrm{~Hz}, 7 \alpha-\mathrm{H}), 4.62(1 \mathrm{H}, \mathrm{ddt}, J=10.7,10.7$, 6.4, $4.2 \mathrm{~Hz}, 3 \alpha-\mathrm{H}), 5.31(1 \mathrm{H}, \mathrm{dd}, J=2.0,2.2 \mathrm{~Hz}, 6-\mathrm{H}) .{ }^{13} \mathrm{C} \mathrm{NMR}$ $\left(75 \mathrm{MHz}, \mathrm{CDCl}_{3}\right)$ ppm 11.8, 18.7, 19.0, $21.0\left(\mathrm{CH}_{2}\right), 21.4,22.5$, 22.8, $23.8\left(\mathrm{CH}_{2}\right), 26.3\left(\mathrm{CH}_{2}\right), 27.7\left(\mathrm{CH}_{2}\right), 28.0,28.5\left(\mathrm{CH}_{2}\right), 35.7$, $36.2\left(\mathrm{CH}_{2}\right), 36.5(\mathrm{C}-10), 36.6\left(\mathrm{CH}_{2}\right), 37.6\left(\mathrm{CH}_{2}\right), 39.4\left(\mathrm{CH}_{2}\right), 39.5$ $\left(\mathrm{CH}_{2}\right), 40.7,42.9(\mathrm{C}-13), 48.1,55.4,55.8,73.2,73.4,126.2(\mathrm{C}-6)$, 142.3 (C-5), $170.5\left(\mathrm{CH}_{3} \mathrm{COO}\right)$. MS (ESI) $\mathrm{m} / \mathrm{z}(\%): 443.5$ (100) $[\mathrm{M}-\mathrm{H}]^{+}, 429.3$ (48), 371.9 (58), 368.3 (77), 331.7 (53), 268.9 (68), 221.0 (61).

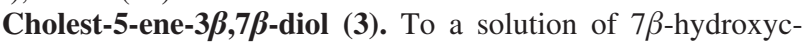
holest-5-en-3 $\beta$-yl acetate $(4,407 \mathrm{mg} ; 0.915 \mathrm{mmol})$ in ethanol (12 $\mathrm{mL})$ and $\mathrm{CH}_{2} \mathrm{Cl}_{2}(4 \mathrm{~mL})$ was added $\mathrm{NaOH} 15 \%(1.8 \mathrm{~mL} ; 6.862$ $\mathrm{mmol})$. The mixture was stirred at $\mathrm{rt}$ for $2 \mathrm{~h}$, poured into $\mathrm{HCl}(5 \%$ aq soln) until neutralization, and evaporated to dryness. The residue was extracted with ethyl acetate and the resulting organic phase washed with water, dried (anhydrous $\mathrm{Na}_{2} \mathrm{SO}_{4}$ ), and evaporated to yield the crude product. Column chromatography of the crude product (petroleum ether-ethyl acetate, 2:1 to $1: 1$ ) afforded the pure cholest-5-ene-3 $\beta, 7 \beta$-diol $(3,350 \mathrm{mg}, 95 \%) \mathrm{mp} 178-179{ }^{\circ} \mathrm{C}$ (EtOH); lit. ${ }^{66} 177-178^{\circ} \mathrm{C}$. IR (film) 3306, 2930, 2867, 1466, 1379, 1053, $949 \mathrm{~cm}^{-1}$. ${ }^{1} \mathrm{H}$ NMR $\left(300 \mathrm{MHz}, \mathrm{CDCl}_{3}\right) \mathrm{ppm} 0.69(3 \mathrm{H}, \mathrm{s}$, $\mathrm{CH}_{3}-18$ ), 0.86 and 0.87 (each $3 \mathrm{H}, 2 \mathrm{~d}, J=6.6 \mathrm{~Hz}, 26-\mathrm{CH}_{3}$ and $\left.27-\mathrm{CH}_{3}\right), 0.92\left(3 \mathrm{H}, \mathrm{d}, J=6.6 \mathrm{~Hz}, \mathrm{CH}_{3}-21\right), 1.05\left(3 \mathrm{H}, \mathrm{s}, \mathrm{CH}_{3}-19\right)$, $3.55(1 \mathrm{H}$, ddt, $J=11.3,11.3,5.0,4.3 \mathrm{~Hz}, 3 \alpha-\mathrm{H}), 3.85(1 \mathrm{H}, \mathrm{td}, J$ $=8.0,2.2,2.2 \mathrm{~Hz}, 7 \alpha-\mathrm{H}), 5.29(\mathrm{t}, J=2.2,2.2 \mathrm{~Hz}, 6-\mathrm{H}) .{ }^{13} \mathrm{C} \mathrm{NMR}$ (75 $\left.\mathrm{MHz}, \mathrm{CDCl}_{3}\right)$ ppm 11.8, 18.7, 19.1, $21.0\left(\mathrm{CH}_{2}\right), 22.5,22.8$, $23.8\left(\mathrm{CH}_{2}\right), 26.4\left(\mathrm{CH}_{2}\right), 28.0,28.5\left(\mathrm{CH}_{2}\right), 31.5\left(\mathrm{CH}_{2}\right), 35.7,36.2$ $\left(\mathrm{CH}_{2}\right), 36.4(\mathrm{C}-10), 36.9\left(\mathrm{CH}_{2}\right), 39.5\left(\mathrm{CH}_{2}\right), 39.5\left(\mathrm{CH}_{2}\right), 40.8,41.7$ $\left(\mathrm{CH}_{2}\right), 42.9$ (C-13), 48.2, 55.4, 55.9, 71.4, 73.3, 125.4 (C-6), 143.4 (C-5). MS (ESI) $\mathrm{m} / \mathrm{z}(\%): 403.9(100)[\mathrm{M}+\mathrm{H}]^{+}, 367.1(62), 365.0$ (68), 301.1 (48), 286.3 (81), 278.7 (45), 104.8).

$7 \alpha$-Hydroxycholest-5-en-3 $\beta$-yl acetate (6) and Cholest-5-ene$\mathbf{3 \beta , 7} \boldsymbol{\alpha}$-diol (5). To a solution of 7-oxo-cholest-5-en-3 $\beta$-yl acetate $(250 \mathrm{mg} ; 0.565 \mathrm{mmol})$ in THF $(10 \mathrm{~mL})$ was slowly added L-Selectride $1 \mathrm{M}(675 \mu \mathrm{L} ; 0.675 \mathrm{mmol})$ at $-70{ }^{\circ} \mathrm{C}$ (methanol bath cooled in Cryocool apparatus). The mixture was stirred at $-65^{\circ} \mathrm{C}$ for $9 \mathrm{~h}$. Reaction was hydrolyzed with water $(0.8 \mathrm{~mL})$ and warmed 
up to $0{ }^{\circ} \mathrm{C}$. The organoborane was oxidized with $\mathrm{NaOH}(6 \mathrm{M}$ aq soln, $0.8 \mathrm{~mL})$ and $\mathrm{H}_{2} \mathrm{O}_{2}(30 \%$ aq soln, $0.8 \mathrm{~mL})$ for $35 \mathrm{~min}$. Then most of the THF was removed under reduce pressure, and the residue diluted with water. The crude product was extracted with $\mathrm{CH}_{2} \mathrm{Cl}_{2}$, dried with anhydrous $\mathrm{Na}_{2} \mathrm{SO}_{4}$, filtered, and concentrated under vacuum to yield a white crude product $(230 \mathrm{mg})$. Column chromatography of the crude product (petroleum ether-ethyl acetate, $2: 1$ to $1: 3$ ) afforded in order of elution the pure $7 \alpha$-hydroxycholest5 -en-3 $\beta$-yl acetate $(6,112 \mathrm{mg}, 44.6 \%) \mathrm{mp} 139-140{ }^{\circ} \mathrm{C}(\mathrm{EtOH})$; lit. $^{67} 139-140{ }^{\circ} \mathrm{C}$. IR (film) $3420,3035,2942,2867,1734,1471$, 1373, 1245, 1030, $757 \mathrm{~cm}^{-1}$. ${ }^{1} \mathrm{H}$ NMR $\left(300 \mathrm{MHz}, \mathrm{CDCl}_{3}\right) \mathrm{ppm}$ $0.68\left(\mathrm{CH}_{3}-18\right), 0.86$ and 0.86 (each $3 \mathrm{H}, 2 \mathrm{~d}, J=6.6 \mathrm{~Hz}, 26-\mathrm{CH}_{3}$ and $\left.27-\mathrm{CH}_{3}\right), 0.92\left(3 \mathrm{H}, \mathrm{d}, J=6.6 \mathrm{~Hz}, \mathrm{CH}_{3}-21\right), 1.00\left(3 \mathrm{H}, \mathrm{s}, \mathrm{CH}_{3^{-}}\right.$ 19), $2.03\left(3 \mathrm{H}, \mathrm{s}, 3 \beta-\mathrm{CH}_{3} \mathrm{COO}\right), 3.84(1 \mathrm{H}, \mathrm{m}, 7 \beta-\mathrm{H}), 4.64$ (ddt, $J$ $=10.4,10.4,6.2,4.2 \mathrm{~Hz}, 3 \alpha-\mathrm{H}), 5.63(\mathrm{dd}, J=5.2,1.5 \mathrm{~Hz}, 6-\mathrm{H})$. ${ }^{13} \mathrm{C} \mathrm{NMR}\left(75 \mathrm{MHz}, \mathrm{CDCl}_{3}\right) \mathrm{ppm} 11.6,18.2,18.7,20.6\left(\mathrm{CH}_{2}\right), 21.4$, 22.5, 22.8, $23.7\left(\mathrm{CH}_{2}\right), 24.2\left(\mathrm{CH}_{2}\right), 27.5\left(\mathrm{CH}_{2}\right), 28.0,28.2\left(\mathrm{CH}_{2}\right)$, 35.8, 36.1 $\left(\mathrm{CH}_{2}\right), 36.7\left(\mathrm{CH}_{2}\right), 37.4,37.4(\mathrm{C}-10), 37.9\left(\mathrm{CH}_{2}\right), 39.1$ $\left(\mathrm{CH}_{2}\right), 39.45\left(\mathrm{CH}_{2}\right), 42.1(\mathrm{C}-13), 42.1,49.4,55.8,65.2,73.4,124.7$ (C-6), 145.2 (C-5), $170.4\left(\mathrm{CH}_{3} \mathrm{COO}\right)$. MS (ESI) m/z (\%): 445.7 (42) $[\mathrm{M}+\mathrm{H}]^{+}, 452.9$ (82), 348.7 (53), 309.8 (68), 291.9 (100), 278.8 (46), 172.7 (82), 147.5 (73), and the pure cholest-5-ene$3 \beta, 7 \alpha$-diol (5, $105 \mathrm{mg} ; 46.2 \%) \mathrm{mp} 188-189{ }^{\circ} \mathrm{C}$ (EtOH); lit. ${ }^{67}$ $186.5-189^{\circ} \mathrm{C}$. IR (film) 3337, 3030, 2936, 2867, 1466, 1379, 1053, 949, $757 \mathrm{~cm}^{-1} .{ }^{1} \mathrm{H}$ NMR (300 MHz, $\left.\mathrm{CDCl}_{3}\right) \mathrm{ppm} 0.69\left(3 \mathrm{H}, \mathrm{s}, \mathrm{CH}_{3^{-}}\right.$ 18 ), 0.86 and 0.87 (each $3 \mathrm{H}, 2 \mathrm{~d}, J=6.6 \mathrm{~Hz}, 26-\mathrm{CH}_{3}$ and $27-\mathrm{CH}_{3}$ ), $0.93\left(3 \mathrm{H}, \mathrm{d}, J=6.6 \mathrm{~Hz}, \mathrm{CH}_{3}-21\right), 1.00\left(3 \mathrm{H}, \mathrm{s}, \mathrm{CH}_{3}-19\right), 3.59(1 \mathrm{H}$, ddt, $J=11.0,11.0,5.4,4.2 \mathrm{~Hz}, 3 \alpha-\mathrm{H}), 3.86(1 \mathrm{H}$, ddd, $J=5.2$, $3.5,1.5 \mathrm{~Hz}, 7 \beta-\mathrm{H}), 5.61(\mathrm{dd}, J=5.2,1.5 \mathrm{~Hz}, 6-\mathrm{H}) .{ }^{13} \mathrm{C} \mathrm{NMR}(75$ $\left.\mathrm{MHz}, \mathrm{CDCl}_{3}\right)$ ppm 11.60, 18.2, 18.7, $20.7\left(\mathrm{CH}_{2}\right), 22.6,22.8,23.7$ $\left(\mathrm{CH}_{2}\right), 24.3\left(\mathrm{CH}_{2}\right), 28.0,28.2\left(\mathrm{CH}_{2}\right), 31.3\left(\mathrm{CH}_{2}\right), 35.7,36.1\left(\mathrm{CH}_{2}\right)$, $37.0\left(\mathrm{CH}_{2}\right), 37.4(\mathrm{C}-10), 37.5,39.1\left(\mathrm{CH}_{2}\right), 39.5\left(\mathrm{CH}_{2}\right), 42.0\left(\mathrm{CH}_{2}\right)$, 42.1 (C-13), 42.2, 49.4, 55.8, 65.3, $71.2,123.8$ (C-6), 146.2 (C-5). MS (ESI) $m / z(\%): 403.9(50)[\mathrm{M}+\mathrm{H}]^{+}, 384.2$ (100), 367.3 (48), 349.8 (61), 246.6 (34), 216.8 (53).

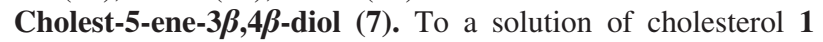
(1200 mg, $3.104 \mathrm{mmol})$ in toluene $(16 \mathrm{~mL})$ a hot solution of selenium dioxide $(960 \mathrm{mg}, 8.652 \mathrm{mmol})$ in acetic acid $98 \%$ (12 $\mathrm{mL})$ ) was added. The reaction mixture was stirred for $90 \mathrm{~min}$ at $90{ }^{\circ} \mathrm{C}$ and then stopped by the addition of sodium acetate $(2.4 \mathrm{~g})$. Reaction mixture was stirred for $10 \mathrm{~min}$ at room temperature and then filtered and extracted with toluene. The toluene solution was washed with water, dried under anhydrous $\mathrm{Na}_{2} \mathrm{SO}_{4}$, and concentrated under vacuum to give a brown crude product. Flash chromatography (gradient of petroleum ether-ethyl acetate, starting from 8:1) afforded the 7 pure compound $(624.8 \mathrm{mg}, 50 \%) \mathrm{mp}$ $176-177{ }^{\circ} \mathrm{C}$ (EtOH); lit. ${ }^{66} 176-177{ }^{\circ} \mathrm{C}$. IR (film) 3408, 2940, 2870, 1457, 1365, 1072, 966, 841, 762, $641 \mathrm{~cm}^{-1}$. ${ }^{1} \mathrm{H}$ NMR $(300$ $\left.\mathrm{MHz}, \mathrm{CDCl}_{3}\right) \mathrm{ppm} 0.68\left(3 \mathrm{H}, \mathrm{s}, 18-\mathrm{CH}_{3}\right), 0.86$ and 0.87 (each $3 \mathrm{H}$, $2 \mathrm{~d}, J=6.6 \mathrm{~Hz}, 26-\mathrm{CH}_{3}$ and $\left.27-\mathrm{CH}_{3}\right), 0.91(3 \mathrm{H}, \mathrm{d}, J=6.6 \mathrm{~Hz}$, $\left.21-\mathrm{CH}_{3}\right), 1.18\left(3 \mathrm{H}, \mathrm{s}, 19-\mathrm{CH}_{3}\right), 3.56(1 \mathrm{H}, \mathrm{td}, J=11.8,4.0,4.0 \mathrm{~Hz}$, $3 \alpha-\mathrm{H}), 4.13(1 \mathrm{H}, \mathrm{d}, J=4.0 \mathrm{~Hz}, 4 \alpha-\mathrm{H}), 5.68(1 \mathrm{H}, \mathrm{dd}, J=4.9,1.9$ $\mathrm{Hz}, 6-\mathrm{H}) .{ }^{13} \mathrm{C} \mathrm{NMR}\left(75 \mathrm{MHz}, \mathrm{CDCl}_{3}\right) \mathrm{ppm} \mathrm{11.8,} \mathrm{18.7,} 20.5\left(\mathrm{CH}_{2}\right)$, 21.0, 22.5, 22.8, $23.8\left(\mathrm{CH}_{2}\right), 24.2\left(\mathrm{CH}_{2}\right), 25.3\left(\mathrm{CH}_{2}\right), 28.0,28.2$ $\left(\mathrm{CH}_{2}\right), 31.8,32.0\left(\mathrm{CH}_{2}\right), 35.8,36.0(\mathrm{C}-10), 36.1\left(\mathrm{CH}_{2}\right), 36.9\left(\mathrm{CH}_{2}\right)$, $39.5\left(\mathrm{CH}_{2}\right), 39.6\left(\mathrm{CH}_{2}\right), 42.26(\mathrm{C}-13), 50.1,56.0,56.9,72.4,77.2$, 128.8 (C-6), 142.7 (C-5). MS (ESI) $\mathrm{m} / z$ (\%) 401.7 (68) $[\mathrm{M}-\mathrm{H}]^{+}$, 387.7 (24), 293.7 (35), 270.4 (27), 265.2 (100), 201.0 (27).

Cholest-4-en-3/ -ol (9). To a solution of cholestenone (400 mg, $1.040 \mathrm{mmol}$ ) and cerium trichloride heptahydrate $(387.5 \mathrm{mg}, 1.040$ $\mathrm{mmol})$ in a mixture of tetrahydrofuran $(6 \mathrm{~mL})$ and methanol $(3$ $\mathrm{mL}$ ) at $0{ }^{\circ} \mathrm{C}$ was added slowly and portionwised sodium borohydride $(78.7 \mathrm{mg}, 2.080 \mathrm{mmol})$. The reaction mixture was stirred at $0{ }^{\circ} \mathrm{C}$ for $15 \mathrm{~min}$ and after concentrated under vacuum. The residue was dissolved in ethyl acetate and organic phase washed sequentially with $\mathrm{HCl}\left(5 \%\right.$ aq soln), $\mathrm{NaHCO}_{3}$ (sat. soln), and water, dried over anhydrous $\mathrm{MgSO}_{4}$, filtrated, and evaporated to yield a white crude product (398 mg, 99\%). Pure cholest-4-en-3 $\beta$-ol (9, $362 \mathrm{mg}$, $90 \%$ ) was obtained by flash chromatography (petroleum ether/ethyl acetate $16: 1) \mathrm{mp} 135-136{ }^{\circ} \mathrm{C}(\mathrm{EtOH})$; lit. ${ }^{68} 133.5-134.5^{\circ} \mathrm{C}$. IR (film) $3354,2928,2867,1654,1465,1377,1045,878,854,753$ $\mathrm{cm}^{-1} \cdot{ }^{1} \mathrm{H}$ NMR $\left(300 \mathrm{MHz}, \mathrm{CDCl}_{3}\right)$ ppm $0.67\left(3 \mathrm{H}, \mathrm{s}, 18-\mathrm{CH}_{3}\right), 0.86$ and 0.86 (each $3 \mathrm{H}, 2 \mathrm{~d}, J=6.5 \mathrm{~Hz}, 26-\mathrm{CH}_{3}$ and $\left.27-\mathrm{CH}_{3}\right), 0.90$ $\left(3 \mathrm{H}, \mathrm{d}, J=6.5 \mathrm{~Hz}, 21-\mathrm{CH}_{3}\right), 1.05\left(3 \mathrm{H}, \mathrm{s}, 19-\mathrm{CH}_{3}\right), 4.15(1 \mathrm{H}, \mathrm{m}$, $3 \alpha-\mathrm{H}), 5.27(1 \mathrm{H}, \mathrm{d}, J=1.7 \mathrm{~Hz}, 4-\mathrm{H}) .{ }^{13} \mathrm{C} \mathrm{NMR}\left(75 \mathrm{MHz}, \mathrm{CDCl}_{3}\right)$ ppm 11.9, 18.6, 18.9, $21.0\left(\mathrm{CH}_{2}\right), 22.5,22.8,23.8\left(\mathrm{CH}_{2}\right), 24.2$ $\left(\mathrm{CH}_{2}\right), 28.0,28.2\left(\mathrm{CH}_{2}\right), 29.5\left(\mathrm{CH}_{2}\right), 32.2\left(\mathrm{CH}_{2}\right), 33.1\left(\mathrm{CH}_{2}\right), 35.3$ $\left(\mathrm{CH}_{2}\right), 35.8,35.9,36.1\left(\mathrm{CH}_{2}\right), 37.3(\mathrm{C}-10), 39.5\left(\mathrm{CH}_{2}\right), 39.8\left(\mathrm{CH}_{2}\right)$, 42.4 (C-13), 54.4, 56.1, 56.1, 68.0 (C-3), 123.2 (C-4), 147.8 (C-5). MS (ESI) $\mathrm{m} / \mathrm{z}(\%) 385.6(83)[\mathrm{M}-\mathrm{H}]^{+}, 329.1$ (65), $311.5(84)$, 294.8 (57), 279.3 (66), 249.1 (100), 111.0 (96).

Chemical Synthesis of Epoxysterols. General Procedure for the Epoxidation Using MMPP. According to the data presented in Table 1, to a solution of the steroid in the appropriate solvent, MMPP was added as a single portion. The suspension was stirred for the periods of time, and temperatures indicated in Table 1, until total substrate consumption (TLC control). Then reaction was stopped by cooling and filtered and concentrated under vacuum. The white solid residue was dissolved in ethyl acetate (saturated in water) and the resulting organic phase was washed with $\mathrm{Na}_{2} \mathrm{SO}_{3}$ $\left(10 \%\right.$ aq), $\mathrm{NaHCO}_{3}$ (sat. aq), and water, dried with anhydrous $\mathrm{Na}_{2} \mathrm{SO}_{4}$, filtered, and evaporated to yield a white foam crude product.

$7 \alpha$-Hydroxy-5 $\alpha, 6 \alpha$-epoxycholestan- $3 \beta$-yl Acetate (6a). To a solution of $7 \alpha$-hydroxy-cholest-5-en-3 $\beta$ yl-acetate $(\mathbf{6}, 80 \mathrm{mg}, 0.180$ $\mathrm{mmoL}$ ) in refluxing $\mathrm{CH}_{3} \mathrm{CN}(5.4 \mathrm{~mL}$ ) was added MMPP (98 mg, $0.198 \mathrm{mmoL}$ ). The reaction mixture was stirred under reflux temperature for $40 \mathrm{~min}$ and then cooled to room temperature, filtered, and concentrated under vacuum. The residue was dissolved in ethyl acetate and washed sequentially with $\mathrm{Na}_{2} \mathrm{SO}_{3}(10 \% \mathrm{aq})$, $\mathrm{NaHCO}_{3}$ (sat. aq), and water, dried with anhydrous $\mathrm{Na}_{2} \mathrm{SO}_{4}$, filtered, and evaporated to yield a white foam crude product ( $82 \mathrm{mg}, 99 \%$ ). Flash chromatography (petroleum ether, ethyl acetate $6: 1$ ) of the crude product afforded the pure $7 \alpha$-hydroxy- $5 \alpha, 6 \alpha$-epoxycholestan$3 \beta$-yl-acetate (6a, $50.6 \mathrm{mg}, 61 \%$ ). IR (film) 3515, 2950, 2867, 1746, 1468, 1363, 1248, 1036, $870 \mathrm{~cm}^{-1}$. ${ }^{1} \mathrm{H}$ NMR (300 MHz, $\mathrm{CDCl}_{3}$ ) ppm $0.61\left(3 \mathrm{H}, \mathrm{s}, 18-\mathrm{CH}_{3}\right), 0.85$ and 0.86 (each $3 \mathrm{H}, 2 \mathrm{~d}, J=6.6$ $\mathrm{Hz}, 26-\mathrm{CH}_{3}$ and $\left.27-\mathrm{CH}_{3}\right), 0.90\left(3 \mathrm{H}, \mathrm{d}, J=6.6 \mathrm{~Hz}, 21-\mathrm{CH}_{3}\right), 1.08$ $\left(3 \mathrm{H}, \mathrm{s}, 19-\mathrm{CH}_{3}\right), 2.02\left(3 \mathrm{H}, \mathrm{s}, 3 \beta-\mathrm{CH}_{3} \mathrm{COO}\right), 3.23(1 \mathrm{H}, \mathrm{d}, J=4.7$ $\mathrm{Hz}, 6 \beta-\mathrm{H}), 3.86(1 \mathrm{H}, \mathrm{bs}, 7 \beta-\mathrm{H}), 4.94(1 \mathrm{H}, \mathrm{tt}, J=11.3,11.3,5.0$, $5.0 \mathrm{~Hz}, 3 \alpha-\mathrm{H}) .{ }^{13} \mathrm{C}$ NMR $\left(75 \mathrm{MHz}, \mathrm{CDCl}_{3}\right) \mathrm{ppm} \mathrm{11.6,} \mathrm{15.9,} \mathrm{18.7,}$ $20.2\left(\mathrm{CH}_{2}\right), 21.3,22.5,22.8,23.6\left(\mathrm{CH}_{2}\right), 24.4\left(\mathrm{CH}_{2}\right), 27.0\left(\mathrm{CH}_{2}\right)$, 28.0, 28.1 $\left(\mathrm{CH}_{2}\right), 32.2\left(\mathrm{CH}_{2}\right), 35.5(\mathrm{C}-10), 35.7,35.8\left(\mathrm{CH}_{2}\right), 36.1$ $\left(\mathrm{CH}_{2}\right), 36.8,37.1,38.7\left(\mathrm{CH}_{2}\right), 39.4\left(\mathrm{CH}_{2}\right), 41.8(\mathrm{C}-13), 48.7,55.4$, 62.6, 64.7, 68.8 (C-5), 71.1, $170.2\left(\mathrm{CH}_{3} \mathrm{COO}\right)$.

Enzymatic Acylation of Epoxysterols. $5 \alpha, 6 \alpha-E p o x y c h o l e s t a n-$ $3 \beta$-ol (1a) and $5 \beta, 6 \beta$-Epoxycholestan-3 $\beta$-yl Acetate (2b). To a solution of 5,6-epoxy-cholestan- $3 \beta$-ol (75 $\mathrm{mg}, \alpha / \beta$ ratio 78:22) in toluene $(4.5 \mathrm{~mL})$ and vinyl acetate $(0.5 \mathrm{~mL})$, Novozym 435 (42 $\mathrm{mg}$ ) was added and the reaction shaken $200 \mathrm{rpm}$ at $45^{\circ} \mathrm{C}$. After $24 \mathrm{~h}$, the enzyme was filtered and the solvent evaporated. Flash chromatography (petroleum ether, ethyl acetate 7:3) afforded in the following elution run the $5 \beta, 6 \beta$-epoxycholestan- $3 \beta$-yl-acetate $(\mathbf{2 b}$, $16.6 \mathrm{mg}, 20 \%$ yield). IR (film) 2948, 2867, 1728, 1466, 1373, 1245, 1041, $757 \mathrm{~cm}^{-1}$. ${ }^{1} \mathrm{H}$ NMR $\left(300 \mathrm{MHz}, \mathrm{CDCl}_{3}\right) \mathrm{ppm} 0.64(3 \mathrm{H}, \mathrm{s}$, $\left.18-\mathrm{CH}_{3}\right), 0.86$ and 0.86 (each $3 \mathrm{H}, 2 \mathrm{~d}, J=6.6 \mathrm{~Hz}, 26-\mathrm{CH}_{3}$ and $\left.27-\mathrm{CH}_{3}\right), 0.88\left(3 \mathrm{H}, \mathrm{d}, J=6.6 \mathrm{~Hz}, 21-\mathrm{CH}_{3}\right), 1.00\left(3 \mathrm{H}, \mathrm{s}, 19-\mathrm{CH}_{3}\right)$, $2.03\left(3 \mathrm{H}, \mathrm{s}, 3 \beta-\mathrm{CH}_{3} \mathrm{COO}\right), 3.08(1 \mathrm{H}, \mathrm{d}, J=2.4 \mathrm{~Hz}, 6 \alpha-\mathrm{H}), 4.77$ $(1 \mathrm{H}, \mathrm{tdd}, J=11.9,10.0,4.8,4.8 \mathrm{~Hz}, 3 \alpha-\mathrm{H}) .{ }^{13} \mathrm{C} \mathrm{NMR}(75 \mathrm{MHz}$, $\left.\mathrm{CDCl}_{3}\right)$ ppm 11.7, 17.0, 18.6, 21.3, $21.9\left(\mathrm{CH}_{2}\right), 22.5,22.8,23.8$ $\left(\mathrm{CH}_{2}\right), 24.1\left(\mathrm{CH}_{2}\right), 27.2\left(\mathrm{CH}_{2}\right), 28.0,28.1\left(\mathrm{CH}_{2}\right), 29.7,32.4\left(\mathrm{CH}_{2}\right)$, $35.0(\mathrm{C}-10), 35.7,36.1\left(\mathrm{CH}_{2}\right), 36.6\left(\mathrm{CH}_{2}\right), 38.0\left(\mathrm{CH}_{2}\right), 39.5\left(\mathrm{CH}_{2}\right)$, $39.7\left(\mathrm{CH}_{2}\right), 42.2(\mathrm{C}-13), 50.9,56.1(2 \mathrm{C}), 62.5(\mathrm{C}-5), 63.6(\mathrm{C}-6)$, 71.3 (C-3), 170.6 ( $\left.\mathrm{CH}_{3} \mathrm{COO}\right) .5 \alpha, 6 \alpha$-Epoxy-cholestan- $3 \beta$-ol (1a, $58 \mathrm{mg}, 77 \%$ yield) $\mathrm{mp} 141-142{ }^{\circ} \mathrm{C}(\mathrm{EtOH})$; lit. ${ }^{69} 140-141.5^{\circ} \mathrm{C}$. IR (film) 3398, 2942, 2867, 1466, 1379, 1036, $763 \mathrm{~cm}^{-1} .{ }^{1} \mathrm{H}$ NMR $\left(300 \mathrm{MHz}, \mathrm{CDCl}_{3}\right) \mathrm{ppm} 0.61\left(3 \mathrm{H}, \mathrm{s}, 18-\mathrm{CH}_{3}\right), 0.86$ and 0.87 (each $3 \mathrm{H}, 2 \mathrm{~d}, J=6.6 \mathrm{~Hz}, 26-\mathrm{CH}_{3}$ and $\left.27-\mathrm{CH}_{3}\right), 0.89(3 \mathrm{H}, \mathrm{d}, J=6.6 \mathrm{~Hz}$, $\left.21-\mathrm{CH}_{3}\right), 1.07\left(3 \mathrm{H}, \mathrm{s}, 19-\mathrm{CH}_{3}\right), 2.91(1 \mathrm{H}, \mathrm{d}, J=4.4 \mathrm{~Hz}, 6 \beta-\mathrm{H})$, $3.92(1 \mathrm{H}, \mathrm{tt}, J=11.4,11.4,5,5 \mathrm{~Hz}, 3 \alpha-\mathrm{H}) .{ }^{13} \mathrm{C} \mathrm{NMR}(75 \mathrm{MHz}$, $\left.\mathrm{CDCl}_{3}\right)$ ppm 11.8, 15.9, 18.6, $20.6\left(\mathrm{CH}_{2}\right), 22.5,22.8,23.8\left(\mathrm{CH}_{2}\right)$, $24.0\left(\mathrm{CH}_{2}\right), 28.0,28.0\left(\mathrm{CH}_{2}\right), 28.8\left(\mathrm{CH}_{2}\right), 29.8,31.0\left(\mathrm{CH}_{2}\right), 32.4$ 
$\left(\mathrm{CH}_{2}\right), 34.8(\mathrm{C}-10)$, 35.7, $36.1\left(\mathrm{CH}_{2}\right), 39.4\left(\mathrm{CH}_{2}\right), 39.5\left(\mathrm{CH}_{2}\right), 39.8$ $\left(\mathrm{CH}_{2}\right), 42.3(\mathrm{C}-13), 42.5,55.8,56.8,59.3,65.7(\mathrm{C}-5), 68.7 . \mathrm{MS}$ (ESI) $\mathrm{m} / \mathrm{z}(\%): 403.6(50)[\mathrm{M}+\mathrm{H}]^{+}, 385.0$ (100); positive mode, $m / z[\mathrm{M}+\mathrm{Na}]^{+}$calcd for $\mathrm{C}_{27} \mathrm{H}_{46} \mathrm{O}_{2} \mathrm{Na}$ : 425.3390; found: 425.3386 .

$\mathbf{5} \boldsymbol{\beta}, \mathbf{6} \boldsymbol{\beta}$-Epoxycholestan-3 $\boldsymbol{\beta}$-ol (1b). To a solution of 5,6-epoxycholestan-3 $\beta$-ol (130 mg, $\alpha / \beta$ ratio 78:22) in toluene $(7 \mathrm{~mL})$ and vinyl acetate $(2 \mathrm{~mL})$, lipase AY $(880 \mathrm{mg})$ was added and the reaction shaken at $200 \mathrm{rpm}$ at $45{ }^{\circ} \mathrm{C}$. After 3 days, the enzyme was filtered and the solvent evaporated. Flash chromatography (petroleum ether, ethyl acetate 9:1 to $3: 2$, with $0.1 \%$ of $\mathrm{Et}_{3} \mathrm{~N} \mathrm{v} / \mathrm{v}$ ) afforded in the following elution run a mixture of 5,6-epoxycholestan-3 $\beta$-yl acetate (2a,2b, $112 \mathrm{mg}, \alpha / \beta$ ratio 91:09, 78\% yield) and the pure $5 \beta, 6 \beta$-epoxycholestan- $3 \beta$-ol (1b, $20.3 \mathrm{mg}, 15.6 \%) \mathrm{mp}$ $132-133{ }^{\circ} \mathrm{C}$ (EtOH); lit. $^{70} 131-132{ }^{\circ} \mathrm{C}$. IR (film) 3392, 2936, 2867, 1471, 1379, 1268, 1059, 937, $757 \mathrm{~cm}^{-1}$. ${ }^{1} \mathrm{H}$ NMR $(300 \mathrm{MHz}$, $\left.\mathrm{CDCl}_{3}\right)$ ppm $0.64\left(3 \mathrm{H}, \mathrm{s}, 18-\mathrm{CH}_{3}\right), 0.86$ and 0.87 (each $3 \mathrm{H}, 2 \mathrm{~d}, J$ $=6.6 \mathrm{~Hz}, 26-\mathrm{CH}_{3}$ and $\left.27-\mathrm{CH}_{3}\right), 0.89\left(3 \mathrm{H}, \mathrm{d}, J=6.6 \mathrm{~Hz}, 21-\mathrm{CH}_{3}\right)$, $1.00\left(3 \mathrm{H}, \mathrm{s}, 19-\mathrm{CH}_{3}\right), 3.07(1 \mathrm{H}, \mathrm{d}, J=2.4 \mathrm{~Hz}, 6 \alpha-\mathrm{H}), 3.70(1 \mathrm{H}$, $\mathrm{m}, 3 \alpha-\mathrm{H}) .{ }^{13} \mathrm{C}$ NMR $\left(75 \mathrm{MHz}, \mathrm{CDCl}_{3}\right) \delta \mathrm{ppm} 11.7,17.0,18.6$, $22.0\left(\mathrm{CH}_{2}\right), 22.5,22.8,23.8\left(\mathrm{CH}_{2}\right), 24.2\left(\mathrm{CH}_{2}\right), 28.0,28.1\left(\mathrm{CH}_{2}\right)$, 29.7, $31.0\left(\mathrm{CH}_{2}\right), 32.6\left(\mathrm{CH}_{2}\right), 34.8(\mathrm{C}-10), 35.7,36.1\left(\mathrm{CH}_{2}\right), 37.2$ $\left(\mathrm{CH}_{2}\right), 39.5\left(\mathrm{CH}_{2}\right), 39.8\left(\mathrm{CH}_{2}\right), 42.2\left(\mathrm{CH}_{2}\right), 42.2(\mathrm{C}-13), 51.3,56.2$, 56.2, 62.9 (C-5), 63.7, 69.4. MS (ESI) $\mathrm{m} / \mathrm{z}(\%)$ : 403.6 (96) [M + $\mathrm{H}^{+}, 384.8$ (100), 292.5 (62), 254.0 (32), 114.5 (25). HRMS (ESI), positive mode, $m / z,[\mathrm{M}+\mathrm{Na}]^{+}$calcd for $\mathrm{C}_{27} \mathrm{H}_{46} \mathrm{O}_{2} \mathrm{Na}$ : 425.3390; found 425.3396 .

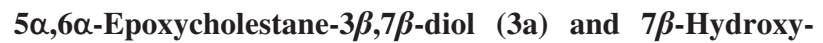
$\mathbf{5} \boldsymbol{\beta}, \mathbf{6} \boldsymbol{\beta}$-epoxycholestan-3 $\boldsymbol{\beta}$-yl Acetate (4b). To a solution of 5,6epoxy-cholestan- $3 \beta, 7 \beta$-diol ( $81 \mathrm{mg}$, ratio $\alpha / \beta$ 44:56) in toluene ( 8 $\mathrm{mL})$ and vinyl acetate $(1 \mathrm{~mL})$, Novozym $435(180 \mathrm{mg})$ was added and the reaction shaken $200 \mathrm{rpm}$ at $45^{\circ} \mathrm{C}$. After $24 \mathrm{~h}$, the enzyme was filtered and the solvent evaporated. Flash chromatography (chloroform, methanol 99:1 to 95:5) afforded the $7 \beta$-hydroxy-5 $\beta, 6 \beta$ epoxycholestan-3 $\beta$-yl-acetate (4b, $49 \mathrm{mg}, 55 \%$ ). IR (film) 3468 , 2950, 2867, 1738, 1468, 1368, 1239, 1036, $754 \mathrm{~cm}^{-1}$. ${ }^{1} \mathrm{H}$ NMR $\left(300 \mathrm{MHz}, \mathrm{CDCl}_{3}\right) \delta \mathrm{ppm} 0.62\left(3 \mathrm{H}, \mathrm{s}, 18-\mathrm{CH}_{3}\right), 0.71(1 \mathrm{H}, \mathrm{m}), 0.84$ and 0.84 (each $3 \mathrm{H}, 2 \mathrm{~d}, J=6.6 \mathrm{~Hz}, 26-\mathrm{CH}_{3}$ and $27-\mathrm{CH}_{3}$ ), 0.88 $\left(3 \mathrm{H}, \mathrm{d}, J=6.5 \mathrm{~Hz}, 21-\mathrm{CH}_{3}\right), 0.99\left(3 \mathrm{H}, \mathrm{s}, 19-\mathrm{CH}_{3}\right), 2.01(3 \mathrm{H}, \mathrm{s}$, $\left.3 \beta-\mathrm{CH}_{3} \mathrm{COO}\right), 3.13(1 \mathrm{H}, \mathrm{d}, J=1.5 \mathrm{~Hz}, 6 \alpha-\mathrm{H}), 3.49(1 \mathrm{H}, \mathrm{dd}, J=$ $8.7,1.5 \mathrm{~Hz}, 7 \alpha-\mathrm{H}), 4.75(1 \mathrm{H}, \mathrm{tdd}, J=11.9,9.7,4.8,4.8 \mathrm{~Hz}, 3 \alpha-$ H). ${ }^{13} \mathrm{C} \mathrm{NMR}\left(75 \mathrm{MHz}, \mathrm{CDCl}_{3}\right) \delta \mathrm{ppm} \mathrm{11.7,} \mathrm{16.8,} \mathrm{18.7,} \mathrm{21.2,} 21.8$ $\left(\mathrm{CH}_{2}\right), 22.5,22.8,23.8\left(\mathrm{CH}_{2}\right), 27.0\left(\mathrm{CH}_{2}\right), 27.2\left(\mathrm{CH}_{2}\right), 27.9,28.5$ $\left(\mathrm{CH}_{2}\right), 34.3(\mathrm{C}-10), 35.6,36.1\left(\mathrm{CH}_{2}\right), 36.3\left(\mathrm{CH}_{2}\right), 37.5\left(\mathrm{CH}_{2}\right), 38.1$, $39.4\left(\mathrm{CH}_{2}\right), 39.4\left(\mathrm{CH}_{2}\right), 42.9(\mathrm{C}-13), 49.4,55.1,55.4,66.7(\mathrm{C}-5)$, 67.4, 70.9, 74.5, 170.4 ( $\left.\mathrm{CH}_{3} \mathrm{COO}\right) .5 \alpha, 6 \alpha$-Epoxy-cholestane- $3 \beta, 7 \beta$ diol (3a, $35.4 \mathrm{mg}, 44 \%$ yield) $\mathrm{mp} 153-154{ }^{\circ} \mathrm{C}(\mathrm{EtOH})$; lit. $^{71}$ 153-155 ${ }^{\circ} \mathrm{C}$. IR (film) 3381, 2948, 2867, 1466, 1378, 1041, 734 $\mathrm{cm}^{-1} .{ }^{1} \mathrm{H}$ NMR $\left(300 \mathrm{MHz}, \mathrm{CDCl}_{3}\right) \delta \mathrm{ppm} 0.63\left(3 \mathrm{H}, \mathrm{s}, 18-\mathrm{CH}_{3}\right)$, 0.84 and 0.85 (each $3 \mathrm{H}, 2 \mathrm{~d}, J=6.6 \mathrm{~Hz}, 26-\mathrm{CH}_{3}$ and $27-\mathrm{CH}_{3}$ ), $0.88\left(3 \mathrm{H}, \mathrm{d}, J=6.6 \mathrm{~Hz}, 21-\mathrm{CH}_{3}\right), 1.08\left(3 \mathrm{H}, \mathrm{s}, 19-\mathrm{CH}_{3}\right), 2.86(1 \mathrm{H}$, s, $6 \beta-\mathrm{H}), 3.67(1 \mathrm{H}, \mathrm{d}, J=6.6 \mathrm{~Hz}, 7 \alpha-\mathrm{H}), 3.86(1 \mathrm{H}, \mathrm{tt}, J=10.9$, 10.9, 4.7, $4.7 \mathrm{~Hz}, 3 \alpha-\mathrm{H}) .{ }^{13} \mathrm{C} \mathrm{NMR}\left(75 \mathrm{MHz}, \mathrm{CDCl}_{3}\right) \delta \mathrm{ppm} 11.8$, 16.1, 18.6, $20.5\left(\mathrm{CH}_{2}\right), 22.5,22.8,23.8\left(\mathrm{CH}_{2}\right), 25.2\left(\mathrm{CH}_{2}\right), 28.0$, $28.2\left(\mathrm{CH}_{2}\right), 30.9\left(\mathrm{CH}_{2}\right), 32.3\left(\mathrm{CH}_{2}\right), 34.6(\mathrm{C}-10), 35.7,36.1\left(\mathrm{CH}_{2}\right)$, $39.3\left(\mathrm{CH}_{2}\right), 39.4\left(\mathrm{CH}_{2}\right), 39.7,40.0,42.7(\mathrm{C}-13), 55.5,55.8,62.7$, 66.2 (C-5), 68.5, 70.3. MS (ESI) $m / z(\%): 419.2(20)[\mathrm{M}+\mathrm{H}]^{+}$, 401.9 (14), 383.6 (15), 367.8 (18), 352.7 (28), 232.6 (11), 102.6 (63), 101.6 (100). HRMS (ESI), positive mode, $\mathrm{m} / z[\mathrm{M}+\mathrm{Na}]^{+}$ calcd for $\mathrm{C}_{27} \mathrm{H}_{46} \mathrm{O}_{3} \mathrm{Na}$ : 441.3339; found: 441.3335 .

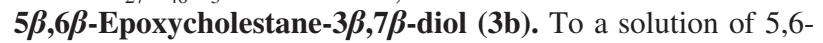
epoxy-cholestan- $3 \beta, 7 \beta$-diol (60 mg, ratio $\alpha / \beta$ 44:56) in toluene (6 $\mathrm{mL})$ and vinyl acetate $(0.6 \mathrm{~mL})$, lipase AY $(53 \mathrm{mg})$ was added and the reaction shaken $200 \mathrm{rpm}$ at $45^{\circ} \mathrm{C}$. After $24 \mathrm{~h}$ the enzyme was filtered and the solvent evaporated. Flash chromatography (petroleum ether, ethyl acetate $2: 1$ to $1: 2$ ) afforded the $7 \beta$-hydroxy-5,6epoxycholestan- $3 \beta$-yl-acetate mixture $(\mathbf{4 a}, \mathbf{4 b}, 35 \mathrm{mg}, \alpha / \beta$ ratio 79 : $21,53 \%)$ and the pure $5 \beta, 6 \beta$-epoxy-cholestane- $3 \beta, 7 \beta$-diol $(\mathbf{3 b}, 26.3$ $\mathrm{mg}, 44 \%$ yield) $\mathrm{mp} 168-170{ }^{\circ} \mathrm{C}(\mathrm{EtOH})$; lit. $^{72} 170-171{ }^{\circ} \mathrm{C}$. IR (film) 3366, 2942, 2867, 1466, 1379, 1059, $763 \mathrm{~cm}^{-1} .{ }^{1} \mathrm{H}$ NMR $\left(500 \mathrm{MHz}, \mathrm{CDCl}_{3}\right) \delta$ ppm $0.64\left(3 \mathrm{H}, \mathrm{s}, 18-\mathrm{CH}_{3}\right), 0.71(1 \mathrm{H}, \mathrm{dt}, J=$ $11.4,11.4,5.6 \mathrm{~Hz}), 0.86$ and 0.86 (each $3 \mathrm{H}, 2 \mathrm{~d}, J=6.6 \mathrm{~Hz}, 26-$
$\mathrm{CH}_{3}$ and $\left.27-\mathrm{CH}_{3}\right), 0.90\left(3 \mathrm{H}, \mathrm{d}, J=6.6 \mathrm{~Hz}, 21-\mathrm{CH}_{3}\right), 1.00(3 \mathrm{H}, \mathrm{s}$, $\left.19-\mathrm{CH}_{3}\right), 3.12(1 \mathrm{H}, \mathrm{d}, J=1.6 \mathrm{~Hz}, 6 \alpha-\mathrm{H}), 3.50(1 \mathrm{H}, \mathrm{m}, 7 \alpha-\mathrm{H})$, $3.70(1 \mathrm{H}, \mathrm{tdd}, J=11.6,9.9,4.5,4.5 \mathrm{~Hz}, 3 \alpha-\mathrm{H}) .{ }^{13} \mathrm{C} \mathrm{NMR}(126$ $\left.\mathrm{MHz}, \mathrm{CDCl}_{3}\right) \delta \mathrm{ppm} 11.8,16.8,18.8,22.0\left(\mathrm{CH}_{2}\right), 22.5,22.8,23.8$ $\left(\mathrm{CH}_{2}\right), 27.2\left(\mathrm{CH}_{2}\right), 28.0,28.5\left(\mathrm{CH}_{2}\right), 30.9\left(\mathrm{CH}_{2}\right), 34.2(\mathrm{C}-10), 35.7$, $36.2\left(\mathrm{CH}_{2}\right), 36.9\left(\mathrm{CH}_{2}\right), 38.3,39.5\left(\mathrm{CH}_{2}\right), 39.6\left(\mathrm{CH}_{2}\right), 41.7\left(\mathrm{CH}_{2}\right)$, 43.0 (C-13), 49.8, 55.3, 55.5, 67.2 (C-5), 67.5, 69.1, 74.8. MS (ESI) $\mathrm{m} / \mathrm{z}(\%): 419.6$ (74) $[\mathrm{M}+\mathrm{H}]^{+}, 413.5$ (26), 402.6 (100). HRMS (ESI), positive mode, $\mathrm{m} / z[\mathrm{M}+\mathrm{Na}]^{+}$calcd for $\mathrm{C}_{27} \mathrm{H}_{46} \mathrm{O}_{3} \mathrm{Na}$ : 441.3339; found: 441.3328 .

$5 \alpha, 6 \alpha-E p o x y c h o l e s t a n e-3 \beta, 7 \alpha-d i o l$ (5a) and $7 \alpha-H y d r o x y-$

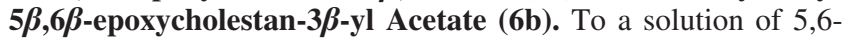
epoxycholestane-3 $\beta, 7 \alpha$-diol (50 mg, ratio $\alpha / \beta$ 89:11) in toluene (2 $\mathrm{mL})$ and vinyl acetate $(0.3 \mu \mathrm{L})$, Novozym $435(55 \mathrm{mg})$ was added and the reaction shaken $200 \mathrm{rpm}$ at $45^{\circ} \mathrm{C}$. After $24 \mathrm{~h}$, the enzyme was filtered and the solvent evaporated. Flash chromatography (chloroform, methanol 97:3) afforded according to elution run the pure $7 \alpha$-hydroxy- $5 \beta, 6 \beta$-epoxycholestan- $3 \beta$-yl-acetate $(6 \mathbf{b}, 5 \mathrm{mg}$, $9 \%) .{ }^{1} \mathrm{H}$ NMR $\left(300 \mathrm{MHz}, \mathrm{CDCl}_{3}\right) \delta$ ppm $0.66\left(3 \mathrm{H}, \mathrm{s}, \mathrm{CH}_{3}-18\right)$, 0.86 and 0.87 (each $3 \mathrm{H}, 2 \mathrm{~d}, J=6.6 \mathrm{~Hz}, 26-\mathrm{CH}_{3}$ and $27-\mathrm{CH}_{3}$ ), $0.90\left(3 \mathrm{H}, \mathrm{d}, J=6.6 \mathrm{~Hz}, \mathrm{CH}_{3}-21\right), 1.02\left(3 \mathrm{H}, \mathrm{s}, \mathrm{CH}_{3}-19\right), 2.04(3 \mathrm{H}$, s, $\left.3 \beta-\mathrm{CH}_{3} \mathrm{COO}\right), 3.12(1 \mathrm{H}, \mathrm{d}, J=3.0 \mathrm{~Hz}, 6 \alpha-\mathrm{H}), 4.07(1 \mathrm{H}, \mathrm{t}, J=$ $3.0,3.0 \mathrm{~Hz}, 7 \beta-\mathrm{H}), 4.82$ (1H, ddd, $J=14.8,9.7,4.9 \mathrm{~Hz}, 3 \alpha-\mathrm{H})$. $5 \alpha, 6 \alpha$-Epoxy-cholestane- $3 \beta, 7 \alpha$-diol (5a, $43.5 \mathrm{mg}, 87 \%) \mathrm{mp} 182-$ $183{ }^{\circ} \mathrm{C}$ (EtOH); lit. $^{72} 183-185{ }^{\circ} \mathrm{C}$. IR (film) 3317, 2930, 2867, 1471, 1373, 1041, 960, 874, 722, $664 \mathrm{~cm}^{-1} .{ }^{1} \mathrm{H}$ NMR $(300 \mathrm{MHz}$, $\left.\mathrm{CDCl}_{3}\right) \delta$ ppm $0.62\left(3 \mathrm{H}, \mathrm{s}, \mathrm{CH}_{3}-18\right), 0.86$ and 0.86 (each $3 \mathrm{H}, 2 \mathrm{~d}$, $J=6.6 \mathrm{~Hz}, 26-\mathrm{CH}_{3}$ and $\left.27-\mathrm{CH}_{3}\right), 0.90\left(3 \mathrm{H}, \mathrm{d}, J=6.6 \mathrm{~Hz}, \mathrm{CH}_{3^{-}}\right.$ 21), 1.07 (3H, s, $\left.\mathrm{CH}_{3}-19\right), 3.24(1 \mathrm{H}, \mathrm{d}, J=4.7 \mathrm{~Hz}, 6 \beta-\mathrm{H}), 3.87$ $(1 \mathrm{H}, \mathrm{m}, 7 \beta-\mathrm{H}), 3.92(1 \mathrm{H}, \mathrm{tt}, J=11.2,11.2,4.9,4.9 \mathrm{~Hz}, 3 \alpha-\mathrm{H})$. ${ }^{13} \mathrm{C}$ NMR $\left(75 \mathrm{MHz}, \mathrm{CDCl}_{3}\right) \delta \mathrm{ppm} \mathrm{11.6,} \mathrm{16.0,} \mathrm{18.7,} 20.3\left(\mathrm{CH}_{2}\right)$, 22.5, 22.8, 23.6 $\left(\mathrm{CH}_{2}\right), 24.4\left(\mathrm{CH}_{2}\right), 28.0,28.1\left(\mathrm{CH}_{2}\right), 30.9\left(\mathrm{CH}_{2}\right)$, 32.4 $\left(\mathrm{CH}_{2}\right), 35.4(\mathrm{C}-10), 35.7,36.1,36.9\left(\mathrm{CH}_{2}\right), 37.1,38.8\left(\mathrm{CH}_{2}\right)$, $39.4\left(\mathrm{CH}_{2}\right), 39.5\left(\mathrm{CH}_{2}\right), 41.9(\mathrm{C}-13), 48.8,55.4,62.7,64.8,68.7$, 69.3 (C-5). MS (ESI) $m / z(\%): 419.6(94)[\mathrm{M}+\mathrm{H}]^{+}, 413.4$ (42), 401.4 (100), 384.4 (35), 316.5 (28), 241.4 (35), 148.7 (20), 101.6 (17). HRMS (ESI), positive mode, $\mathrm{m} / \mathrm{z}[\mathrm{M}+\mathrm{Na}]^{+}$calcd for $\mathrm{C}_{27} \mathrm{H}_{46} \mathrm{O}_{3} \mathrm{Na}$ : 441.3339; found: 441.3331 .

$5 \alpha, 6 \alpha$-Epoxycholestane-3 $\beta, 4 \beta$-diol (7a), $4 \beta$-Hydroxy-5 $\beta, 6 \beta$ -

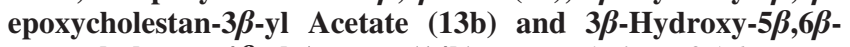
epoxycholestan-4 $\beta$-yl Acetate (14b). To a solution of 5,6 epoxycholestane- $3 \beta, 4 \beta$-diol (176 mg, ratio $\alpha / \beta 43: 57)$ in toluene $(18 \mathrm{~mL})$ and vinyl acetate $(2 \mathrm{~mL})$, Novozym $435(1505 \mathrm{mg})$ was added and the reaction shaken $200 \mathrm{rpm}$ at $45^{\circ} \mathrm{C}$. Reaction was controlled by TLC (petroleum ether, ethyl acetate 1:1, double development). After 7 days, the enzyme was filtered and the solvent evaporated. Flash chromatography (petroleum ether-ethyl acetate, $4: 1$ to $1: 1$ ) yielded accordingly to elution sequence $4 \beta$-hydroxy- $5 \beta, 6 \beta$-epoxycholestan$3 \beta$-yl acetate (13b, $60 \mathrm{mg}, 31 \%)$, mp $155-156^{\circ} \mathrm{C}$ (EtOH). IR (film) 3524, 2955, 2868, 1717, 1454, 1376, 1242, 1044, 918, $760 \mathrm{~cm}^{-1}$. ${ }^{1} \mathrm{H}$ NMR $\left(500 \mathrm{MHz}, \mathrm{CDCl}_{3}\right) \delta \mathrm{ppm} 0.61(1 \mathrm{H}, \mathrm{m}), 0.63(3 \mathrm{H}, \mathrm{s}$, $\left.18-\mathrm{CH}_{3}\right), 0.86$ and 0.86 (each $3 \mathrm{H}, 2 \mathrm{~d}, J=6.6 \mathrm{~Hz}, 26-\mathrm{CH}_{3}$ and $\left.27-\mathrm{CH}_{3}\right), 0.89\left(3 \mathrm{H}, \mathrm{d}, J=6.6 \mathrm{~Hz}, 21-\mathrm{CH}_{3}\right), 1.16\left(3 \mathrm{H}, \mathrm{s}, 19-\mathrm{CH}_{3}\right)$, $2.11\left(3 \mathrm{H}, \mathrm{s}, 3 \beta-\mathrm{CH}_{3} \mathrm{COO}\right), 3.22(1 \mathrm{H}, \mathrm{dd}, J=2.5,1.0 \mathrm{~Hz}, 6 \alpha-\mathrm{H})$, $3.45(1 \mathrm{H}, \mathrm{dd}, J=3.2,1.0 \mathrm{~Hz}, 4 \alpha-\mathrm{H}), 4.82(1 \mathrm{H}, \mathrm{ddd}, J=11.6$,

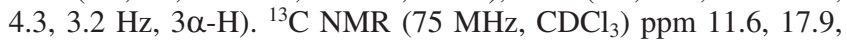
18.6, 21.1 $\left(\mathrm{CH}_{2}\right), 21.1\left(\mathrm{CH}_{2}\right), 21.3,22.5,22.8,23.8\left(\mathrm{CH}_{2}\right), 24.2$ $\left(\mathrm{CH}_{2}\right), 28.0,28.1\left(\mathrm{CH}_{2}\right), 29.6,32.4\left(\mathrm{CH}_{2}\right), 35.0(\mathrm{C}-10), 35.7,36.1$ $\left(\mathrm{CH}_{2}\right), 36.8\left(\mathrm{CH}_{2}\right), 39.5\left(\mathrm{CH}_{2}\right), 39.5\left(\mathrm{CH}_{2}\right), 42.1(\mathrm{C}-13), 51.6,56.1$, 56.2, 63.8 (C-6), 65.2 (C-5), 73.4, 74.9, $170.7\left(\mathrm{CH}_{3} \mathrm{COO}\right)$. MS (ESI) $\mathrm{m} / \mathrm{z}(\%) 461.5(100)[\mathrm{M}+\mathrm{H}]^{+}, 442.5(48), 417.7$ (37), $391.9(25)$, 367.5 (39), 349.2 (28), 325.9 (22). $3 \beta$-Hydroxy-5 $\beta, 6 \beta$-ерохусholestan- $4 \beta$-yl acetate $(\mathbf{1 4 b}, 46 \mathrm{mg}, 24 \%) \mathrm{mp} 153-154{ }^{\circ} \mathrm{C}(\mathrm{EtOH})$. IR (film) 3527, 2953, 2867, 1716, 1454, 1379, 1239, 1047, 914 $\mathrm{cm}^{-1} .{ }^{1} \mathrm{H}$ NMR $\left(500 \mathrm{MHz}, \mathrm{CDCl}_{3}\right) \delta \mathrm{ppm} 0.61(1 \mathrm{H}, \mathrm{m}), 0.62(3 \mathrm{H}$, s, $\left.18-\mathrm{CH}_{3}\right), 0.86$ and 0.86 (each $3 \mathrm{H}, 2 \mathrm{~d}, J=6.6 \mathrm{~Hz}, 26-\mathrm{CH}_{3}$ and $\left.27-\mathrm{CH}_{3}\right), 0.89\left(3 \mathrm{H}, \mathrm{d}, J=6.6 \mathrm{~Hz}, 21-\mathrm{CH}_{3}\right), 1.12\left(3 \mathrm{H}, \mathrm{s}, 19-\mathrm{CH}_{3}\right)$, $2.15\left(3 \mathrm{H}, \mathrm{s}, 4 \beta-\mathrm{CH}_{3} \mathrm{COO}\right), 3.21(1 \mathrm{H}, \mathrm{dd}, J=2.2,0.5 \mathrm{~Hz}, 6 \alpha-\mathrm{H})$, 3.78 (1H, ddd, $J=11.4,4.3,3.5 \mathrm{~Hz}, 3 \alpha-\mathrm{H}), 4.72$ (dd, $J=3.5,0.5$ $\mathrm{Hz}, 4 \alpha-\mathrm{H}) .{ }^{13} \mathrm{C}$ NMR $\left(126 \mathrm{MHz}, \mathrm{CDCl}_{3}\right) \mathrm{ppm} \mathrm{11.6,} \mathrm{17.3,} \mathrm{18.6,}$ 21.1, $21.4\left(\mathrm{CH}_{2}\right), 22.5,22.8,23.7\left(\mathrm{CH}_{2}\right), 24.2\left(\mathrm{CH}_{2}\right), 24.7\left(\mathrm{CH}_{2}\right)$, 
28.0, $28.1\left(\mathrm{CH}_{2}\right), 29.6,32.4\left(\mathrm{CH}_{2}\right), 34.9(\mathrm{C}-10), 35.7,36.1\left(\mathrm{CH}_{2}\right)$, $37.1\left(\mathrm{CH}_{2}\right), 39.4\left(\mathrm{CH}_{2}\right), 39.6\left(\mathrm{CH}_{2}\right), 42.1(\mathrm{C}-13), 51.7,56.1,56.1$, 62.7 (C-5), 62.9 (C-6), 70.7 (C-7), 79.2 (C-3), $171.7\left(\mathrm{CH}_{3} \mathrm{COO}\right)$. $\mathrm{MS} \mathrm{m} / z(\%) 461.4(59)[\mathrm{M}+\mathrm{H}]^{+}, 444.4$ (69), 441.0 (100), 382.3 (70), 377.0 (44), 273.9 (63). HRMS (ESI), positive mode, $\mathrm{m} / \mathrm{z}$ [M $+\mathrm{Na}]^{+}$calcd for $\mathrm{C}_{29} \mathrm{H}_{48} \mathrm{O}_{4} \mathrm{Na}$ : 483.3444; found: $483.3437 .5 \alpha, 6 \alpha-$ Epoxycholestane-3 $\beta, 4 \beta$-diol (7a, $74 \mathrm{mg}, 42 \%) \mathrm{mp} \mathrm{205-206}{ }^{\circ} \mathrm{C}$ (EtOH); lit. ${ }^{73} 195.5-198{ }^{\circ} \mathrm{C}$. IR (film) 3356, 2942, 2867, 1454, 1373, 1047, 972, $763 \mathrm{~cm}^{-1} .{ }^{1} \mathrm{H}$ NMR $\left(500 \mathrm{MHz}, \mathrm{CDCl}_{3}\right) \mathrm{ppm} 0.61$ $\left(3 \mathrm{H}, \mathrm{s}, 18-\mathrm{CH}_{3}\right), 0.86$ and 0.86 (each $3 \mathrm{H}, 2 \mathrm{~d}, J=6.6 \mathrm{~Hz}, 26-\mathrm{CH}_{3}$ and $\left.27-\mathrm{CH}_{3}\right), 0.88\left(3 \mathrm{H}, \mathrm{d}, J=6.6 \mathrm{~Hz}, 21-\mathrm{CH}_{3}\right), 1.22(3 \mathrm{H}, \mathrm{s}, 19-$ $\left.\mathrm{CH}_{3}\right), 3.03(1 \mathrm{H}, \mathrm{dd}, J=4.2,6 \beta-\mathrm{H}), 3.19(1 \mathrm{H}, \mathrm{dd}, J=3.5,1.0 \mathrm{~Hz}$, $4 \alpha-\mathrm{H}), 3.86(1 \mathrm{H}$, ddd, $J=12.0,5.0,3.5 \mathrm{~Hz}, 3 \alpha-\mathrm{H}) .{ }^{13} \mathrm{C}$ NMR $\left(126 \mathrm{MHz}, \mathrm{CDCl}_{3}\right)$ ppm 11.9, 15.3, 18.7, $20.0\left(\mathrm{CH}_{2}\right), 22.6,22.8$, $23.9\left(\mathrm{CH}_{2}\right), 24.0\left(\mathrm{CH}_{2}\right), 25.6\left(\mathrm{CH}_{2}\right), 28.0,28.1\left(\mathrm{CH}_{2}\right), 28.3\left(\mathrm{CH}_{2}\right)$, 30.0, $32.7\left(\mathrm{CH}_{2}\right), 34.3(\mathrm{C}-10), 35.8,36.2\left(\mathrm{CH}_{2}\right), 39.4\left(\mathrm{CH}_{2}\right), 39.5$ $\left(\mathrm{CH}_{2}\right), 42.45$ (C-13), 43.4, 55.9, 57.0, 59.3, 64.7 (C-5), 70.1, 77.4. MS (ESI) $m / z(\%): 419.7$ (71) $[\mathrm{M}+\mathrm{H}]^{+}, 418.1$ (36), 402.0 (17), 391.0 (22), 239.4 (25), 102 (100). HRMS (ESI), positive mode, $m / z[\mathrm{M}+\mathrm{Na}]^{+}$calcd for $\mathrm{C}_{27} \mathrm{H}_{46} \mathrm{O}_{3} \mathrm{Na}$ : 441.3339; found: 441.3346 .

$4 \alpha, 5 \alpha$-Epoxycholestan-3 $\beta$-ol (9a) and $4 \beta, 5 \beta$-Epoxycholestan$\mathbf{3} \beta$-yl Acetate (10b). To a solution of 4,5-epoxy-3 $\beta$-cholestanol (110 mg, ratio $\alpha / \beta 21: 79)$ in toluene $(10 \mathrm{~mL})$ and vinyl acetate $(1.3 \mathrm{~mL})$, Novozym $435(1434 \mathrm{mg})$ was added and the reaction shaken $200 \mathrm{rpm}$ at $45{ }^{\circ} \mathrm{C}$. Reaction was controlled by TLC (petroleum ether, ethyl acetate 3:1, double development). After 5 days, the enzyme was filtered and the solvent evaporated. Flash chromatography (petroleum ether, ethyl acetate 10:1 to $3: 1$ ) afforded in the following elution run the $4 \beta, 5 \beta$-epoxycholestan- $3 \beta$-yl acetate (10b, $92 \mathrm{mg}, 76 \%) .{ }^{1} \mathrm{H}$ NMR $\left(300 \mathrm{MHz}, \mathrm{CDCl}_{3}\right) \mathrm{ppm} 0.68(3 \mathrm{H}, \mathrm{s}$, $18-\mathrm{CH}_{3}$ ), 0.86 and 0.87 (each $3 \mathrm{H}, 2 \mathrm{~d}, J=6.6 \mathrm{~Hz}, 26-\mathrm{CH}_{3}$ and $\left.27-\mathrm{CH}_{3}\right), 0.90\left(3 \mathrm{H}, \mathrm{d}, J=6.6 \mathrm{~Hz} 21-\mathrm{CH}_{3}\right), 1.04\left(3 \mathrm{H}, \mathrm{s}, 19-\mathrm{CH}_{3}\right)$, $2.10\left(1 \mathrm{H}, \mathrm{s}, 3 \beta-\mathrm{CH}_{3} \mathrm{COO}\right), 3.16(1 \mathrm{H}, \mathrm{d}, J=3.6 \mathrm{~Hz}, 4 \alpha-\mathrm{H}), 5.13$ $(1 \mathrm{H}, \mathrm{m}, 3 \alpha-\mathrm{H}) .{ }^{13} \mathrm{C} \mathrm{NMR}\left(75 \mathrm{MHz}, \mathrm{CDCl}_{3}\right) \mathrm{ppm} \mathrm{11.9,} \mathrm{18.4,} \mathrm{18.6,}$ 21.2, $21.4\left(\mathrm{CH}_{2}\right), 22.5\left(\mathrm{CH}_{2}\right), 22.5,22.8,23.8\left(\mathrm{CH}_{2}\right), 24.2\left(\mathrm{CH}_{2}\right)$, 28.0, 28.1 $\left(\mathrm{CH}_{2}\right), 29.6\left(\mathrm{CH}_{2}\right), 30.3\left(\mathrm{CH}_{2}\right), 31.2\left(\mathrm{CH}_{2}\right), 35.2,35.7$, $35.8(\mathrm{C}-10), 36.1\left(\mathrm{CH}_{2}\right), 39.5\left(\mathrm{CH}_{2}\right), 39.7\left(\mathrm{CH}_{2}\right), 42.5(\mathrm{C}-13), 49.0$, $56.0,56.2,61.3,66.8(\mathrm{C}-5), 69.0,171.0\left(\mathrm{CH}_{3} \mathrm{COO}\right) .4 \alpha, 5 \alpha-$ Epoxycholestan-3 $\beta$-ol (9a, $22 \mathrm{mg}, 20 \%) \mathrm{mp} 134-136{ }^{\circ} \mathrm{C}$ (EtOH), lit. $^{74} 136-137^{\circ} \mathrm{C}$. IR (film) $3408,2942,2867,1466,1379,960$, $757 \mathrm{~cm}^{-1}$. ${ }^{1} \mathrm{H}$ NMR $\left(300 \mathrm{MHz}, \mathrm{CDCl}_{3}\right) \delta \mathrm{ppm} 0.68(3 \mathrm{H}, \mathrm{s}, 18-$ $\mathrm{CH}_{3}$ ), 0.86 and 0.87 (each $3 \mathrm{H}, 2 \mathrm{~d}, J=6.6 \mathrm{~Hz}, 26-\mathrm{CH}_{3}$ and $27-$ $\left.\mathrm{CH}_{3}\right), 0.90\left(3 \mathrm{H}, \mathrm{d}, J=6.5 \mathrm{~Hz}, 21-\mathrm{CH}_{3}\right), 1.11\left(3 \mathrm{H}, \mathrm{s}, 19-\mathrm{CH}_{3}\right)$, $2.90(1 \mathrm{H}, \mathrm{d}, J=1.0 \mathrm{~Hz}, 4 \beta-\mathrm{H}), 3.99(1 \mathrm{H}, \mathrm{m}, 3 \alpha-\mathrm{H}) .{ }^{13} \mathrm{C} \mathrm{NMR}$ $\left(126 \mathrm{MHz}, \mathrm{CDCl}_{3}\right) \delta \mathrm{ppm} \mathrm{12.1,} \mathrm{17.7,} \mathrm{18.6,} 20.9\left(\mathrm{CH}_{2}\right), 22.6,22.8$, $23.8\left(\mathrm{CH}_{2}\right), 24.2\left(\mathrm{CH}_{2}\right), 27.0\left(\mathrm{CH}_{2}\right), 28.0,28.2\left(\mathrm{CH}_{2}\right), 28.4\left(\mathrm{CH}_{2}\right)$, $28.5\left(\mathrm{CH}_{2}\right), 29.7\left(\mathrm{CH}_{2}\right), 35.5,35.5(\mathrm{C}-10), 35.8,36.1\left(\mathrm{CH}_{2}\right), 39.5$ $\left(\mathrm{CH}_{2}\right), 39.8\left(\mathrm{CH}_{2}\right), 42.6(\mathrm{C}-13), 50.0,55.7,56.2,64.7,66.0,67.4$ (C-5). MS (ESI) $\mathrm{m} / \mathrm{z}(\%): 403.7(86)[\mathrm{M}+\mathrm{H}]^{+}, 399.9(35), 394.7$ (100), 384.8 (84), 370.9 (36), 367.2 (30), 326.2 (32), 311.6 (39), 288.4 (94). HRMS (ESI), positive mode, $\mathrm{m} / z$ [M $+\mathrm{Na}]^{+}$calcd for $\mathrm{C}_{27} \mathrm{H}_{46} \mathrm{O}_{2} \mathrm{Na}$ : 425.3390; found: 425.3381 .

Enzymatic Deacylation of Epoxysterols. $5 \alpha, 6 \alpha$-Epoxycholes-

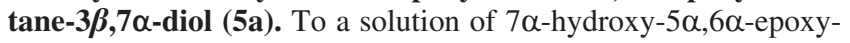
cholestan- $3 \beta$-yl acetate $(6 \mathbf{a}, 40 \mathrm{mg})$ in toluene $(5 \mathrm{~mL})$ and octanol $(0.15 \mathrm{~mL})$, lipase AY (400 $\mathrm{mg})$ was added and the reaction shaken $200 \mathrm{rpm}$ at $45^{\circ} \mathrm{C}$. After 4 days, the enzyme was filtered and the solvent evaporated. 5 $\alpha, 6 \alpha$-Epoxy-cholestane-3 $\beta, 7 \alpha$-diol (5a, $34 \mathrm{mg}$, $94 \%$ yield) was isolated by flash chromatography (petroleum ether, ethyl acetate $2: 1$ to $1: 1$ ).

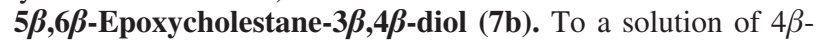
hydroxy- $5 \beta, 6 \beta$-epoxycholestan- $3 \beta$-yl acetate $(\mathbf{1 3 b}, 30 \mathrm{mg})$ in toluene $(4 \mathrm{~mL})$ and octanol $(0.1 \mathrm{~mL})$, Novozym $435(90 \mathrm{mg})$ was added and the reaction shaken $200 \mathrm{rpm}$ at $45^{\circ} \mathrm{C}$. After 20 days, the reaction was stopped, enzyme was filtered, and the solvent concentrated under vacuum. Flash chromatography (petroleum ether, ethyl acetate $4: 1$ to $2: 1$ ) afforded the $5 \beta, 6 \beta$-epoxycholestane$3 \beta, 4 \beta$-diol (7b, $14.2 \mathrm{mg}, 52 \%$ yield) $\mathrm{mp} 175.5-176.5^{\circ} \mathrm{C}(\mathrm{EtOH})$; lit. $^{75} 173-175^{\circ} \mathrm{C}$. IR (film) 3419, 2942, 2867, 1466, 1379, 914, $763 \mathrm{~cm}^{-1} .{ }^{1} \mathrm{H}$ NMR $\left(500 \mathrm{MHz}, \mathrm{CDCl}_{3}\right)$ ppm 0.59 (1H, m), 0.63 $\left(3 \mathrm{H}, \mathrm{s}, 18-\mathrm{CH}_{3}\right), 0.85$ and $0.86\left(\right.$ each $3 \mathrm{H}, 2 \mathrm{~d}, J=6.6 \mathrm{~Hz}, 26-\mathrm{CH}_{3}$ and $\left.27-\mathrm{CH}_{3}\right), 0.89\left(3 \mathrm{H}, \mathrm{d}, J=6.6 \mathrm{~Hz}, 21-\mathrm{CH}_{3}\right), 1.12(3 \mathrm{H}, \mathrm{s}, 19-$ $\left.\mathrm{CH}_{3}\right), 3.19(1 \mathrm{H}, \mathrm{d}, J=2.2 \mathrm{~Hz}, 6 \alpha-\mathrm{H}), 3.35(1 \mathrm{H}, \mathrm{d}, J=3.6 \mathrm{~Hz}$, $4 \alpha-\mathrm{H}), 3.61(1 \mathrm{H}, \mathrm{td}, J=11.6,4.5,3.6 \mathrm{~Hz}, 3 \alpha-\mathrm{H}) .{ }^{13} \mathrm{C}$ NMR $(126$ $\left.\mathrm{MHz}, \mathrm{CDCl}_{3}\right)$ ppm 11.7, 17.8, 18.7, $21.2\left(\mathrm{CH}_{2}\right), 22.5,22.8,23.8$ $\left(\mathrm{CH}_{2}\right), 24.2\left(\mathrm{CH}_{2}\right), 24.8\left(\mathrm{CH}_{2}\right), 28.0,28.1\left(\mathrm{CH}_{2}\right), 29.6,32.5\left(\mathrm{CH}_{2}\right)$, 34.7 (C-10), 35.7, $36.1\left(\mathrm{CH}_{2}\right), 36.9\left(\mathrm{CH}_{2}\right), 39.5\left(\mathrm{CH}_{2}\right), 39.6\left(\mathrm{CH}_{2}\right)$, 42.2 (C-13), 51.5, 56.1, 56.2, 64.0, 65.5 (C-5), 71.2, 77.1. MS (ESI) $\mathrm{m} / \mathrm{z}(\%): 419.8(81)[\mathrm{M}+\mathrm{H}]^{+}, 357.5$ (20), 289.2 (25), 242.7 (24), 102.3 (100). HRMS (ESI), positive mode, $\mathrm{m} / \mathrm{z}[\mathrm{M}+\mathrm{Na}]^{+}$calcd for $\mathrm{C}_{27} \mathrm{H}_{46} \mathrm{O}_{3} \mathrm{Na}$ : 441.3339; found: 441.3343 .

$5 \alpha, 6 \alpha-E p o x y-7-n o r c h o l e s t a n-3 \beta$-ol (11a). To a solution of $5 \alpha, 6 \alpha$-epoxy-7-norcholestan-3 $\beta$-yl-acetate $(\mathbf{1 2 a}, 45 \mathrm{mg})$ in toluene $(5 \mathrm{~mL})$ and octanol $(0.15 \mathrm{~mL})$, lipase AY $(450 \mathrm{mg})$ was added and the reaction shaken $200 \mathrm{rpm}$ at $45{ }^{\circ} \mathrm{C}$. After 3 days, the enzyme was filtered and the solvent evaporated. $5 \alpha, 6 \alpha$-Epoxy-7-norcholestan-3 $\beta$-ol (11a, $39 \mathrm{mg}, 96 \%$ yield) was isolated by flash chromatography (petroleum ether, ethyl acetate $3: 1$ to $1: 1) \mathrm{mp}$ 138.5-139.5 ${ }^{\circ} \mathrm{C}$ (EtOH); lit. ${ }^{76} 139-140{ }^{\circ} \mathrm{C}$. IR (film) 3366, 2936, 2872, 1460, 1379, 1083, $757 \mathrm{~cm}^{-1} .{ }^{1} \mathrm{H}$ NMR (600 MHz, $\mathrm{CDCl}_{3}$ ) ppm $0.63\left(3 \mathrm{H}, \mathrm{s}, 18-\mathrm{CH}_{3}\right), 0.86$ and 0.87 (each $3 \mathrm{H}, 2 \mathrm{~d}, J=6.6$ $\mathrm{Hz}, 26-\mathrm{CH}_{3}$ and $\left.27-\mathrm{CH}_{3}\right), 0.89\left(3 \mathrm{H}, \mathrm{s}, 19-\mathrm{CH}_{3}\right), 0.90(3 \mathrm{H}, \mathrm{d}, J=$ $\left.6.6 \mathrm{~Hz}, 21-\mathrm{CH}_{3}\right), 3.26(1 \mathrm{H}, \mathrm{s}, 6 \beta-\mathrm{H}), 3.96(1 \mathrm{H}, \mathrm{m}, 3 \alpha-\mathrm{H}) .{ }^{13} \mathrm{C} \mathrm{NMR}$ (75 MHz, $\mathrm{CDCl}_{3}$ ) ppm 12.1, 15.4, 18.7, 20.9, 22.5, 22.8, 23.9, 24.2, 28.0, 28.5, 30.9, 31.2, 34.6, 35.7, 36.2, 38.8 (C-10), 39.4, 39.8, 42.5, 44.4 (C-13), 48.2, 50.6, 55.5, 60.4, 69.1 (C-5), 69.8. MS (ESI) $\mathrm{m} / \mathrm{z}(\%): 389.7(58)[\mathrm{M}+\mathrm{H}]^{+}, 371.8$ (100), $353.0(28), 339.2(11)$, 269.1 (11). HRMS (ESI), positive mode, $\mathrm{m} / z . \mathrm{M}+\mathrm{Na}]^{+}$calcd for $\mathrm{C}_{26} \mathrm{H}_{44} \mathrm{O}_{2} \mathrm{Na}$ : 411.3233; found 411.3229.

Chemical Deacylation of Epoxysterols. General Procedure for Mild Acetoxy Hydrolysis of Epoxysteroids. 4 $\beta, 5 \beta$-Epoxycholestan-3 $\beta$-ol (9b). To a solution of $4 \beta, 5 \beta$-epoxycholestan- $3 \beta$-yl acetate $(\mathbf{1 0 b}, 40 \mathrm{mg}, 0.090 \mathrm{mmol})$ in methanol $(10 \mathrm{~mL})$ was added sodium carbonate $(19 \mathrm{mg}, 0.180 \mathrm{mmol})$, and the reaction mixture was stirred at room temperature overnight. TLC analysis showed the disappearance of $\mathbf{1 0 b}$ and the formation of a polar compound. Then solvent was concentrated under vacuum and the residue dissolved in dichloromethane, washed with water, and dried over anhydrous sodium sulfate. Evaporation gave a white solid and flash chromatography (petroleum ether, ethyl acetate $8: 1$ to $4: 1$ ) afforded the pure $4 \beta, 5 \beta$-epoxycholestan- $3 \beta$-ol (9b, $34.7 \mathrm{mg}, 96 \%) \mathrm{mp} 96-97$ ${ }^{\circ} \mathrm{C}$ (EtOH); lit. ${ }^{74} 96-97{ }^{\circ} \mathrm{C}$. IR (film) 3415, 2936, 2867, 1466, $1379,1036,855 \mathrm{~cm}^{-1} .{ }^{1} \mathrm{H}$ NMR $\left(500 \mathrm{MHz}, \mathrm{CDCl}_{3}\right) \mathrm{ppm} 0.68(3 \mathrm{H}$, s, $18-\mathrm{CH}_{3}$ ), 0.86 and 0.87 (each $3 \mathrm{H}, 2 \mathrm{~d}, J=6.6 \mathrm{~Hz}, 26-\mathrm{CH}_{3}$ and $\left.27-\mathrm{CH}_{3}\right), 0.90\left(3 \mathrm{H}, \mathrm{d}, J=6.6 \mathrm{~Hz}, 21-\mathrm{CH}_{3}\right), 1.03\left(3 \mathrm{H}, \mathrm{s}, 19-\mathrm{CH}_{3}\right)$, $3.14(1 \mathrm{H}, \mathrm{d}, J=4.8 \mathrm{~Hz}, 4 \alpha-\mathrm{H}), 4.06(1 \mathrm{H}, \mathrm{dt}, J=4.8,4.8,2.5 \mathrm{~Hz}$,

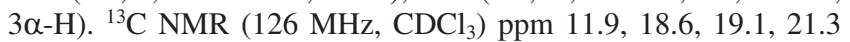
$\left(\mathrm{CH}_{2}\right), 22.8,23.8\left(\mathrm{CH}_{2}\right), 24.3\left(\mathrm{CH}_{2}\right), 25.9\left(\mathrm{CH}_{2}\right), 26.0\left(\mathrm{CH}_{2}\right), 28.0$, $28.2\left(\mathrm{CH}_{2}\right), 30.3\left(\mathrm{CH}_{2}\right), 31.1\left(\mathrm{CH}_{2}\right), 35.0,35.7(\mathrm{C}-10), 36.1\left(\mathrm{CH}_{2}\right)$, 36.1, $39.5\left(\mathrm{CH}_{2}\right), 39.7\left(\mathrm{CH}_{2}\right), 42.5(\mathrm{C}-13), 47.0,56.1,56.2,63.7$, 64.2, 69.0 (C-5). MS (ESI) $\mathrm{m} / \mathrm{z}(\%): 403.7$ (51) $[\mathrm{M}+\mathrm{H}]^{+}, 372.1$ (37), 369.1 (39), 354.4 (100), 296.6 (80), 288.7 (41), 206.8 (54), $72.9(50), 59.2(50)$. HRMS (ESI), positive mode, $\mathrm{m} / \mathrm{z}[\mathrm{M}+\mathrm{Na}]^{+}$ calcd for $\mathrm{C}_{27} \mathrm{H}_{46} \mathrm{O}_{2} \mathrm{Na}$ : 425.3390 ; found: 425.3395 .

Biology. General. HT29 and BJ cell lines were purchased from ATCC, whereas LAMA-84 cells were acquired from DSMZ. Roswell Park Memorial Institute medium with L-glutamine and without sodium bicarbonate (RPMI 1640), resazurin, penicillin, and streptomycin were obtained from Sigma-Aldrich Co. Fetal bovine serum (FBS) and tripsin/EDTA (0.5 g/L) were obtained from Gibco. MycoAlert was purchase from Cambrex Bioscience Verviers, Inc. Cisplatin (Faulplatin, 100 mg/mL, Mayne Pharma, Portugal, Lda) and doxorubicin (doxorubicin hydrochloride for injection, USP, 2 $\mathrm{mg} / \mathrm{mL}$, Faulding, Canada, Inc.) were kindly donated by the Hospital Universitário de Coimbra. A stock solution of $0.1 \mathrm{mg} /$ $\mathrm{mL}$ of resazurin in Dulbecco's phosphate buffer saline (PBS: 1.4 $\mathrm{mM} \mathrm{KH} \mathrm{PO}_{4}, 2.7 \mathrm{mM} \mathrm{KCl}, 4.3 \mathrm{mM} \mathrm{Na} \mathrm{HPO}_{4}, 137 \mathrm{mM} \mathrm{NaCl}, \mathrm{pH}$ 7.4) was prepared and used for the Alamar assay. Absorbance was determined by a Multiscan Ex, Thermo Labsystem, 96-well reader spectrometer.

Cell Lines and Culture Condition. Cytotoxicity of the compounds synthesized was assessed on HT29 (human colon adeno- 
carcinoma; adherent epitheloid cell line), LAMA84 (human chronic myeloid leukemia in blast crisis; suspended/slowly adherent cell line), and the BJ noncancer cell line (human foreskin fibroblast; adherent cell line). Cells were grown at $37{ }^{\circ} \mathrm{C}$ in a humidified atmosphere of $95 \%$ air and 5\% $\mathrm{CO}_{2}$, in RPMI 1640 medium with $0.2 \% \mathrm{NaHCO}_{3}$ and supplemented with $10 \%$ of heat inactivated fetal bovine serum (iFBS), 100 units $/ \mathrm{mL}$ penicillin and $0.1 \mathrm{mg} / \mathrm{mL}$ streptomycin (PS)-culture medium (CM).

Adherent cells were harvested using trypsin for $10 \mathrm{~min}$ at $37^{\circ} \mathrm{C}$ and exponentially growing cells were used throughout. Cells were tested periodically for the presence of mycoplasma with the mycoplasma detection kit MycoAlert.

Cell Viability Assay. Stock solutions of the synthesized sterols were prepared in dimethylsulfoxide (DMSO) and stored at -20 ${ }^{\circ} \mathrm{C}$.

HT2 9 cells were seeded at density of $9 \times 10^{3}$ cells per well in 96-well culture plates, LAMA84 at $10 \times 10^{3}$ cells/well, and BJ at $2 \times 10^{3}$ cells/well in a total volume of $100 \mu \mathrm{L}$ of CM. Cells were incubated overnight and then exposed to different sterol concentrations, containing DMSO, in $100 \mu \mathrm{L}$ of CM. The maximal DMSO concentration in the total medium volume was always lower than $0.6 \%$ (including controls). Compounds $\mathbf{1}, \mathbf{7}$, and $\mathbf{9}$ were dissolved in a mixture of DMSO and tetrahydrofuran (THF) and given to cells in a solvent mixture concentration lower than $0.7 \%$. Compoundinduced cytotoxicity was quantified after $48 \mathrm{~h}$ of exposure by a cell viability colorimetric redox assay using resazurin, ${ }^{48}$ which measures the conversion of resazurin (blue-absorbance at $630 \mathrm{~nm}$ ) to its reduced form, resorufin (pink-absorbance at $540 \mathrm{~nm}$ ) by viable cells. After $48 \mathrm{~h}$ incubation, the medium was removed and replaced by fresh medium, depleted in iFBS and SP, but containing $10 \%$ of resazurin. Cells were further incubated for $2 \mathrm{~h}$ at $37^{\circ} \mathrm{C}$. Absorbance was then measured at 540 and $630 \mathrm{~nm}$ with a plate spectrophotometer and cell viability (CV) calculated for each concentration tested, according to the following formula:

$$
\begin{aligned}
& \mathrm{CV}(\%)= \\
& \quad \frac{\left(\mathrm{Abs}_{540} D-\mathrm{Abs}_{540} R\right)-\left(\mathrm{Abs}_{630} D-\mathrm{Abs}_{630} R\right)}{\left(\mathrm{Abs}_{540} C-\mathrm{Abs}_{540} R\right)-\left(\mathrm{Abs}_{630} C-\mathrm{Abs}_{630} R\right)} \times 100
\end{aligned}
$$

$D$, drug treated cells; $C$, control cells; $R$, resazurin control.

The inhibitory concentration in which $50 \%$ of the cells die $\left(\mathrm{IC}_{50}\right)$ was determined for each compound by plotting the $\mathrm{CV}$ observed for each concentration versus the logarithmized concentration and fitting a nonlinear regression curve. All experiments were performed in triplicates and were repeated at least 3 times. Results were expressed as the mean and are summarized in Table 4.

Acknowledgment. We thank Fundação para a Ciência e Tecnologia (FCT), Portugal, through POCI for financial support. We acknowledge the "Laboratório de Espectroscopia de Massa do Centro de Estudos Farmacêuticos da Universidade de Coimbra", Portugal, for providing data from the LC-MS ${ }^{n}$ (QITMS), integrated in the Portuguese National Mass Spectrometry Network (QNEM). J.F.S. Carvalho also thanks the Fundação para a Ciência e Tecnologia (FCT), Portugal, for a grant (SFRH/BD/18263/2004).

\section{References}

(1) Ferderbar, S.; Pereira, E. C.; Apolinário, E.; Bertolami, M. C.; Faludi, A.; Monte, O.; Calliari, L. E.; Sales, J. E.; Gagliardi, A. R.; Xavier, H. T.; Abdalla, D. S. P. Cholesterol oxides as biomarkers of oxidative stress in type 1 and type 2 diabetes mellitus. Diabetes Metab. Res. Rev. 2007, 23, 35-42.

(2) Glass, C. K.; Saijo, K. Immunology: Oxysterols hold T cells in check. Nature 2008, 455, 40-41.

(3) van Reyk, D. M.; Brown, A. J.; Hult'en, L. M.; Dean, R. T.; Jessup, W. Oxysterols in biological systems: sources, metabolism and pathophysiological relevance. Redox Rep. 2006, 11, 255-262.

(4) Olkkonen, V. M. New Functions for Oxysterols and Their Cellular Receptors. Lipids Insights 2008, 2, 1-9.
(5) Brown, A. J.; Jessup, W. Oxysterols and atherosclerosis. Atherosclerosis 1999, 142, 1-28.

(6) Gill, S.; Chow, R.; Brown, A. J. Sterol regulators of cholesterol homeostasis and beyond: The oxysterol hypothesis revisited and revised. Prog. Lipid Res. 2008, 47, 391-404.

(7) Vejux, A.; Malvitte, L.; Lizard, G. Side effects of oxysterols: cytotoxicity, oxidation, inflammation, and phospholipidosis. Braz. J. Med. Biol. Res. 2008, 41, 545-556.

(8) Murphy, R. C.; Johnson, K. M. Cholesterol, Reactive Oxygen Species, and the Formation of Biologically Active Mediators. J. Biol. Chem. 2008, 283, 15521-15525.

(9) Naz, S.; Kerr, R. G.; Narayanan, R. New antiproliferative epoxysecosterols from Pseudopterogorgia americana. Tetrahedron Lett. $\mathbf{2 0 0 0 ,}$ 41, 6035-6040.

(10) Ahmed, A. F.; Hsieh, Y.-T.; Wen, Z.-H.; Wu, Y.-C.; Sheu, J.-H. Polyoxygenated Sterols from the Formosan Soft Coral Sinularia gibberosa. J. Nat. Prod. 2006, 69, 1275-1279.

(11) Luo, X.; Li, F.; Shinde, P. B.; Hong, J.; Lee, C.-O.; Im, K. S.; Jung, J. H. 26,27-Cyclosterols and Other Polyoxygenated Sterols from a Marine Sponge Topsentia sp. J. Nat. Prod. 2006, 69, 1760-1768.

(12) Misra, L.; Lal, P.; Chaurasia, N. D.; Sangwan, R. S.; Sinha, S.; Tuli, R. Selective reactivity of 2-mercaptoethanol with 5[beta],6[beta]epoxide in steroids from Withania somnifera. Steroids 2008, 73, 245251.

(13) Chen, W.-Y.; Chang, F.-R.; Huang, Z.-Y.; Chen, J.-H.; Wu, Y.-C.; Wu, C.-C. Tubocapsenolide A, a Novel Withanolide, Inhibits Proliferation and Induces Apoptosis in MDA-MB-231 Cells by Thiol Oxidation of Heat Shock Proteins. J. Biol. Chem. 2008, 283, 1718417193.

(14) Parker, R. E.; Isaacs, N. S. Mechanisms Of Epoxide Reactions. Chem. Rev. 1959, 59, 737-799.

(15) Szeliga, J.; Dipple, A. DNA Adduct Formation by Polycyclic Aromatic Hydrocarbon Dihydrodiol Epoxides. Chem. Res. Toxicol. 1998, 11, $1-11$.

(16) Zheng, J.; Cho, M.; Jones, A. D.; Hammock, B. D. Evidence of Quinone Metabolites of Naphthalene Covalently Bound to Sulfur Nucleophiles of Proteins of Murine Clara Cells after Exposure to Naphthalene. Chem. Res. Toxicol. 1997, 10, 1008-1014.

(17) Greene, J. F.; Zheng, J.; Grant, D. F.; Hammock, B. D. Cytotoxicity of 1,2-epoxynaphthalene Is Correlated with Protein Binding and in Situ Glutathione Depletion in Cytochrome P4501A1 Expressing Sf21 Cells. Toxicol. Sci. 2000, 53, 352-360.

(18) Lesuisse, D.; Gourvest, J. F.; Hartmann, C.; Tric, B.; Benslimane, O.; Philibert, D.; Vevert, J. P. Synthesis and evaluation of a new series of mechanism-based aromatase inhibitors. J. Med. Chem. 1992, 35, 1588-1597.

(19) Numazawa, M.; Yamada, K.; Watari, Y.; Ando, M. Improved Synthesis and Molecular Modeling of 4 $\beta, 19$-Dihydroxyandrost-5-en-17-one, an Excellent Inhibitor of Aromatase. Chem. Pharm. Bull. 2002, 50, 703705.

(20) Michne, W. F.; Schroeder, J. D.; Bailey, T. R.; Young, D. C.; Hughes, J. V.; Dutko, F. J. Keto/enol epoxy steroids: a new structural class of HIV-1 tat inhibitors. J. Med. Chem. 1993, 36, 2701-2702.

(21) Michne, W. F.; Schroeder, J. D.; Bailey, T. R.; Neumann, H. C.; Cooke, D.; Young, D. C.; Hughes, J. V.; Kingsley, S. D.; Ryan, K. A.; Putz, H. S.; Shaw, L. J.; Dutko, F. J. Keto/Enol Epoxy Steroids as HIV-1 Tat Inhibitors: Structure-Activity Relationships and Pharmacophore Localization. J. Med. Chem. 1995, 38, 3197-3206.

(22) Zhao, K.; Wang, Y.; Han, L. 4,5-Epoxycholestane-3,6-diols: Templates for generating the full set of eight cholestane-3,5,6-triol stereoisomers in multigram scales, but not for a cholestane-3,4,6-triol. Steroids $\mathbf{2 0 0 7}$, 72, 95-104

(23) Pérez-Ornelas, V.; Cabeza, M.; Bratoeff, E.; Heuze, I.; Sánchez, M.; Ramírez, E.; Naranjo-Rodríguez, E. New 5[alpha]-reductase inhibitors: in vitro and in vivo effects. Steroids 2005, 70, 217-224.

(24) Numazawa, M.; Oshibe, M. 6-Alkyl- and 6-Arylandrost-4-ene-3,17diones as Aromatase Inhibitors. Synthesis and Structure-Activity Relationships. J. Med. Chem. 1994, 37, 1312-1319.

(25) Numazawa, M.; Yoshimura, A. Synthesis and Biochemical Studies of 19-Oxygenated Derivatives of $6 \alpha$ - and $6 \beta$-Methylandrostenediones as Catalytic Probes for the Active Site of Aromatase. Biol. Pharm. Bull. 2000, 23, 1059-1065.

(26) Salvador, J. A. R.; Silvestre, S. M.; Moreira, V. M. Catalytic Epoxidation and syn-Dihydroxylation Reactions in Steroid Chemistry. Curr. Org. Chem. 2008, 12, 492-522.

(27) Ball, P.; Zienelis, K.; Allen, L. Biocatalysis: Synthesis methods that exploit enzymatic activities. Nature 2001, 409, 225-225.

(28) Koeller, K. M.; Wong, C.-H. Enzymes for chemical synthesis. Nature 2001, 409, 232-240.

(29) Hager, L. P.; Allain, E. J. Stereoselective epoxidation of alkenes by chloroperoxidase. U.S. Patent 5358860, 1994.

(30) Lakner, F. J.; Hager, L. P. Chloroperoxidase-mediated asymmetric epoxidation. Synthesis of $(R)$-dimethyl 2-methylaziridine-1,2- 
dicarboxylate-a potential alpha-methylamino acid synthon. Tetrahedron: Asymmetry 1997, 8, 3547-3550.

(31) Farinas, E. T.; Alcalde, M.; Arnold, F. Alkene epoxidation catalyzed by cytochrome P450 BM-3 139-3. Tetrahedron 2004, 60, 525-528.

(32) Rai, G. P.; Sakai, S.; Flórez, A. M.; Mogollon, L.; Hager, L. P. Directed Evolution of Chloroperoxidase for Improved Epoxidation and Chlorination Catalysis. Adv. Synth. Catal. 2001, 343, 638-645.

(33) Choi, W. J.; Choi, C. Y. Production of Chiral Epoxides: Epoxide Hydrolase-catalyzed Enantioselective Hydrolysis. Biotechnol. Bioprocess. Eng. 2005, 10, 167-179.

(34) Cruz Silva, M. M.; Riva, S.; Sá e Melo, M. L. Highly selective lipasemediated discrimination of diastereomeric 5,6-epoxysteroids. Tetrahedron: Asymmetry 2004, 15, 1173-1179.

(35) Carvalho, J. F. S.; Silva, M. M. C.; Sá e Melo, M. L. Highly efficient epoxidation of unsaturated steroids using magnesium bis(monoperoxyphthalate) hexahydrate. Tetrahedron 2009, 65, 2773-2781.

(36) Bjorkhem, I.; Diczfalusy, U. Oxysterols: Friends, Foes, or Just Fellow Passengers? Arterioscler. Thromb. Vasc. Biol. 2002, 22, 734-742.

(37) Bodin, K.; Bretillon, L.; Aden, Y.; Bertilsson, L.; Broome, U.; Einarsson, C.; Diczfalusy, U. Antiepileptic Drugs Increase Plasma Levels of 4beta-Hydroxycholesterol in Humans. Evidence for Involvement of Cytochrome P450 3A4. J. Biol. Chem. 2001, 276, 3868538689.

(38) Princen, H. M. G.; Post, S. M.; Twisk, J. Regulation of Bile Acid Biosynthesis. Curr. Pharm. Des. 1997, 3, 59-84.

(39) Prunet, C.; Petit, J. M.; Ecarnot-Laubriet, A.; Athias, A.; MiguetAlfonsi, C.; Rohmer, J. F.; Steinmetz, E.; Néel, D.; Gambert, P.; Lizard, G. High circulating levels of 7[beta]- and 7[alpha]-hydroxycholesterol and presence of apoptotic and oxidative markers in arterial lesions of normocholesterolemic atherosclerotic patients undergoing endarterectomy. Pathol. Biol. 2006, 54, 22-32.

(40) Ryan, L.; Callaghan, Y. C. O.; Brien, N. M. O. Comparison of the apoptotic processes induced by the oxysterols 7beta-hydroxycholesterol and cholesterol-5beta,6beta-epoxide. Cell Biol. Toxicol. 2004, 20, $313-$ 323.

(41) Lathe, R. Steroid and sterol 7-hydroxylation: ancient pathways. Steroids 2002, 67, 967-977.

(42) Salvador, J. A. R.; Sá e Melo, M. L.; Neves, A. S. C. Copper-Catalysed Allylic Oxidation of Delta5-Steroids by $t$-Butyl Hydroperoxide. Tetrahedron Lett. 1997, 38, 119-122.

(43) Arsenou, E. S.; Koutsourea, A. I.; Fousteris, M. A.; Nikolaropoulos, S. S. Optimization of the allylic oxidation in the synthesis of 7-keto[delta]5-steroidal substrates. Steroids 2003, 68, 407-414.

(44) Kumar, V.; Amann, A.; Ourisson, G.; Luu, B. Stereospecific Syntheses of $7 \beta$-AND $7 \alpha$-Hydroxycholesterols. Synth. Commun. 1987, 17, 12791286.

(45) Rossiter, B. E.; Verhoeven, T. R.; Sharpless, K. B. Stereoselective epoxidation of acyclic allylic alcohols. A correction of our previous work. Tetrahedron Lett. 1979, 20, 4733-4736.

(46) Zhao, K.; Wang, Y.; Billington, D. C. Studies on stereocontrolled epoxidations of bis-alicyclic alcohols in steroidal skeletons: preparation of eight diastereomerically pure epoxides from cholest-4-en-3beta, 6beta-;-3beta,6alpha-;-3alpha,6beta-, and-3alpha,6alpha-diols. Tetrahedron: Asymmetry 2001, 12, 1211-1217.

(47) Cruz Silva, M. M.; Riva, S.; Sá e Melo, M. L. Regioselective enzymatic acylation of vicinal diols of steroids. Tetrahedron 2005, 61, 30653073.

(48) O'Brien, J.; Wilson, I.; Orton, T.; Pognan, F. Investigation of the alamar blue (resazurin) fluorescent dye for the assessment of mammalian cell cytotoxicity. Eur. J. Biochem. 2000, 267, 5421-5426.

(49) Hamid, R.; Rotshteyn, Y.; Rabadi, L.; Parikh, R.; Bullock, P. Comparison of alamar blue and MTT assays for high through-put screening. Toxicol. in Vitro 2004, 18, 703-710.

(50) Cerda, S.; Wilkinson, J.; Broitman, S. Regulation of cholesterol synthesis in four colonic adenocarcinoma cell lines. Lipids 1995, 30, 1083-1092.

(51) Ikonen, E. Cellular cholesterol trafficking and compartmentalization. Nat. Rev. Mol. Cell Biol. 2008, 9, 125-138.

(52) Cummings, J.; Anderson, L.; Willmott, N.; Smyth, J. F. The molecular pharmacology of doxorubicin in vivo. Eur. J. Cancer 1991, 27, 532535 .

(53) Jemal, A.; Siegel, R.; Ward, E.; Hao, Y.; Xu, J.; Murray, T.; Thun, M. J. Cancer Statistics, 2008. Can. Cancer J. Clin. 2008, 58, 71-96.
(54) Goldstein, L. J. MDR1 gene expression in solid tumours. Eur. J. Cancer 1996, 32, 1039-1050.

(55) Ridgway, N. D.; Dawson, P. A.; Ho, Y. K.; Brown, M. S.; Goldstein, J. L. Translocation of oxysterol binding protein to Golgi apparatus triggered by ligand binding. J. Cell Biol. 1992, 116, 307-319.

(56) Brown, A. J.; Leong, S. L.; Dean, R. T.; Jessup, W. 7-Hydroperoxycholesterol and its products in oxidized low density lipoprotein and human atherosclerotic plaque. J. Lipid Res. 1997, 38, 1730-1745.

(57) Kang, K. A.; Chae, S.; Lee, K. H.; Park, M. T.; Lee, S. J.; Lee, Y. S.; Hyun, J. W. Cytotoxic Effect of $7 \beta$-Hydroxycholesterol on Human NCI-H460 Lung Cancer Cells. Biol. Pharm. Bull. 2005, 28, 13771380.

(58) Maier, G.; Bing, G.; Falken, U.; Wagner, E.; Unger, C. Antitumor activity and induction of apoptosis by water-soluble derivatives of 7-beta-hydroxycholesterol in human colon carcinoma cell lines. Anticancer Res. 1999, 19, 4251-4256.

(59) Roussi, S.; Gossé, F.; Aoudé-Werner, D.; Zhang, X.; Marchioni, E.; Geoffroy, P.; Miesch, M.; Raul, F. Mitochondrial perturbation, oxidative stress and lysosomal destabilization are involved in 7-hydroxysitosterol and 7-hydroxycholesterol triggered apoptosis in human colon cancer cells. Apoptosis 2007, 12, 87-96.

(60) Lordan, S. A.; Mackrill, J. J.; O’Brien, N. M. Involvement of Fas Signalling in $7 \beta$-Hydroxycholesterol-and Cholesterol-5 $\beta, 6 \beta$-EpoxideInduced Apoptosis. Int. J. Toxicol. 2008, 27, 279.

(61) Pirillo, A.; Zhu, W.; Roma, P.; Galli, G.; Caruso, D.; Pellegatta, F.; Catapano, A. L. Oxysterols from oxidized LDL are cytotoxic but fail to induce hsp70 expression in endothelial cells. FEBS Lett. 1999, 462, 113-116.

(62) O'Sullivan, A. J.; O'Callaghan, Y. C.; Woods, J. A.; O'Brien, N. M. Toxicity of cholesterol oxidation products to Caco-2 and HepG2 cells: modulatory effects of $\alpha$ - and $\gamma$-tocopherol. J. Appl. Toxicol. 2003, 23, 191-197.

(63) Ryan, L.; O'Callaghan, Y. C.; O'Brien, N. M. The role of the mitochondria in apoptosis induced by $7 \beta$-hydroxycholesterol and cholesterol-5 $\beta, 6 \beta$-epoxide. Br. J. Nutr. 2005, 94, 519-525.

(64) Macdonald, I. A. Detection of bile salts with Komarowsky's reagent and group specific dehydrogenases. J. Chromatogr. 1977, 136, 348352.

(65) Kimura, M.; Muto, T. The Reactions of Cholesteryl Acetate with tertButyl Hydroperoxide and Molybdenum Complexes. Chem. Pharm. Bull. 1981, 29, 35-42.

(66) Li, S.; Pang, J.; Wilson, W. K.; Schroepfer, J. Sterol synthesis. Preparation and characterization of fluorinated and deuterated analogs of oxygenated derivatives of cholesterol. Chem. Phys. Lipids 1999, 99, 33-71.

(67) Nickon, A.; Bagli, J. F. Reactivity and Geometry in Allylic Systems. I. Stereochemistry of Photosensitized Oxygenation of Monoolefins. J. Am. Chem. Soc. 1961, 83, 1498-1508.

(68) Saito, A.; Tanaka, A.; Oritani, T. Highly Diastereoselective Reduction of Bicyclic and Steroidal Conjugated Enones with Dibal in THF-DME. Synth. Commun. 1997, 27, 1969-1973.

(69) Chakravorty, P. N.; Levin, R. H. Studies on Cholesteryl Oxides1. J. Am. Chem. Soc. 1942, 64, 2317-2322.

(70) Baxter, R. A.; Spring, F. S. $\beta$-Cholesterol oxide. J. Chem. Soc. 1943, 613-615.

(71) Romero, M. Notes-Reaction of NBS with Allylic Alcohols. J. Org. Chem. 1957, 22, 1267-1268.

(72) Kawata, M.; Tohma, M.; Sawaya, T.; Kimura, M. A New Product of Cholesterol by Metal-Free Autoxidation in Aqueous Dispersion. Chem. Pharm. Bull. 1976, 24, 3109-3113.

(73) Fieser, L. F.; Goto, T.; Bhattacharyya, B. K. Identification of Ketone

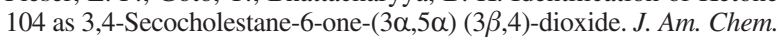
Soc. 1960, 82, 1700-1706.

(74) Collins, D. J. Steroidal $\alpha \beta$-epoxy-ketones. Part I. Rearrangement of $4 \alpha, 5$-epoxy-5a-cholestan-3-one and its $4 \beta, 5 \beta$-isomer by means of the boron trifluoride-ether complex. J. Chem. Soc. 1959, 3919-3928.

(75) Cicala, G.; Curci, R.; Fiorentino, M.; Laricchiuta, O. Stereo- and regioselectivities in the epoxidation of some allylic alcohols by the dioxirane intermediate generated in the reaction of potassium caroate with acetone. J. Org. Chem. 1982, 47, 2670-2673.

(76) Dauben, W. G.; Boswell, G. A.; Templeton, W.; McFarland, J. W.; Berezin, G. H. The Configuration of B-Norsteroid Derivatives. J. Am. Chem. Soc. 1963, 85, 1672-1676.

JM9003973 